\title{
Vodni resursi u poljodjelstvu u sjeveroistočnoj Siriji (namjesništvo Hasaka)
}

\author{
Danijel Orešić, Georgos Bahnan
}

\begin{abstract}
U članku se razmatra upravljanje vodnim resursima za potrebe natapanja poljodjelskih površina u namjesništvu Hasaka u sjeveroistočnoj Siriji potkraj XX. st. Istraživano područje žitnica je Sirije. Veliki zahvati u podzemne i površinske vodne resurse počeli su 1970-ih, uglavnom radi natapanja, i doveli su do značajnih promjena u istraživanom području. Zamjetno je prekomjerno crpljenje vode iz podzemlja.
\end{abstract}

Ključne riječi: Sirija, Hasaka, natapanje, vodni resursi, hidrogeografija

\section{Water Resources in Agriculture in North-Eastern Syria (Governorate Al Hasakah)}

The paper deals with the water resources management in irrigation of agricultural land in the Al Hasakah governorate in north-eastern Syria, at the end of $20^{\text {th }}$ century. The area is the most important Syrian cotton and wheat production area. The use of ground-water and river-water in agriculture, especially since the 1970's has led to significant changes in the area. There is evidence of ground-water overuse.

Key words: Syria, Al Hasakah, irrigaion, water resources, hydrogeography

\section{UVOD}

Sjeveroistok Sirije nalazi se u gornjoj Mezopotamiji i administrativno pripada namjesništvu (sirijskoj provinciji) Hasaka. Njezin humidniji dio jest zavala Gornje Đezire, izdužena smjerom istok - zapad, između Torosa (odnosno gorja Mardin) na sjeveru i gorskog niza Abd al Aziz - Sinđar na jugu. Ovaj prostor odvodnjava rijeka Habur sa svojim pritocima. Zavala je prostrana sinklinala u kojoj su slojevi nagnuti ka jugu pa podzemne vode s Torosa otječu na jug. U Gornjoj Đeziri oblikovana je akumulacija podzemnih voda koje pak rasjedna zona uz sjeverno podnožje planinske strukture Abd al Aziza spriječava u njihovom daljnjem otjecanju prema jugu. To je pogodovalo iskorištavanju vode u podzemlju za natapanje i vodoopskrbu. Južnije od Abd al Aziza nalazi se stepski i polupustinjski dio namjesništva Hasaka koji pripada Donjoj Đeziri kroz koju Habur kao alogena tekućica otječe prema Eufratu. U tom rijetko naseljenom kraju razvijeno je stočarstvo. U žarištu interesa jest dakle Gornja Đezira s obzirom da u tom dijelu namjesništva razvijeno poljodjelstvo. To je kraj u kojem su litološke i klimatske prilike pogodovale razmjerno gustoj hidrografskoj 


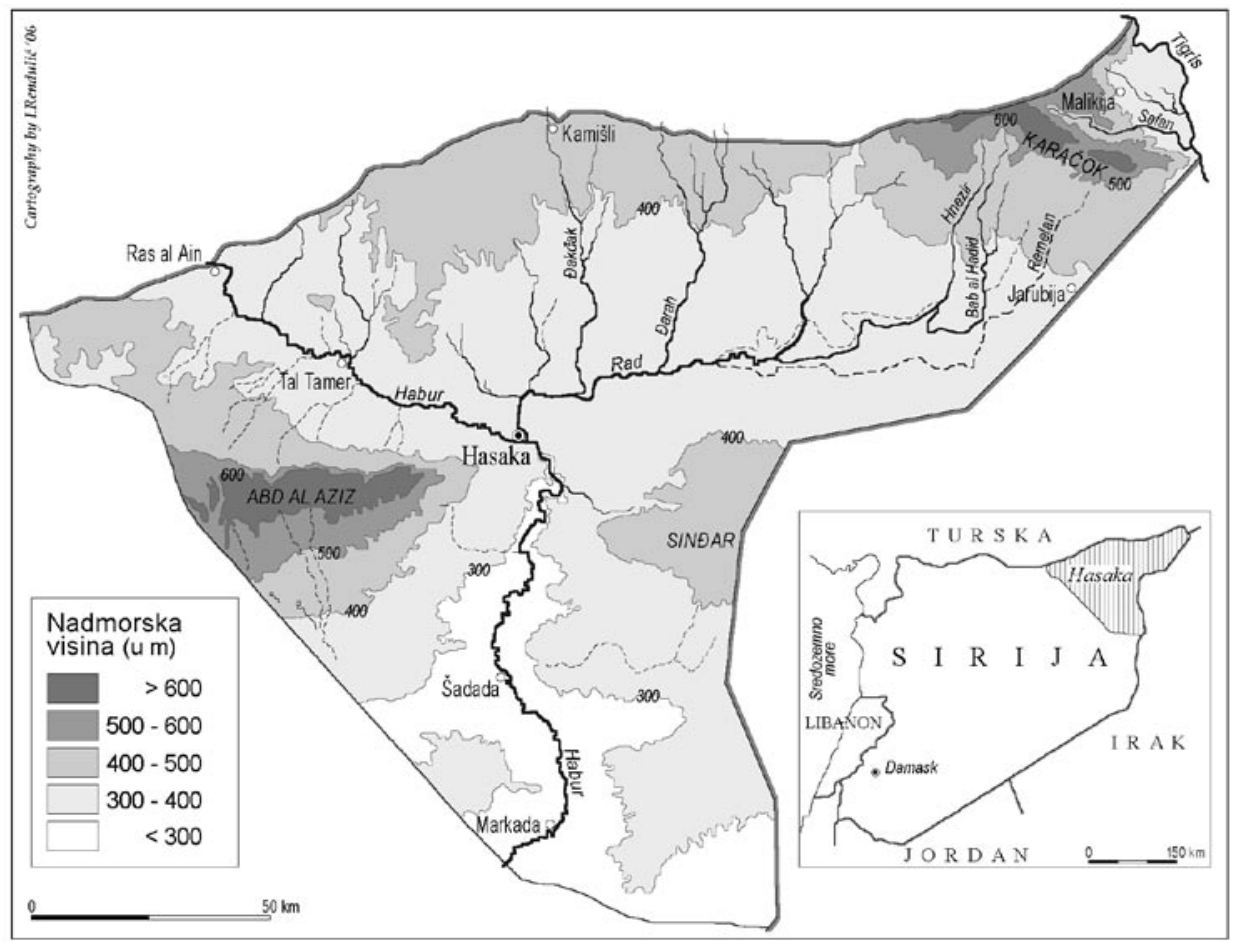

Sl. 1. Namjesništvo Hasaka na sjeveroistoku Sirije

Fig. 1 Governorate Al Hasakah in North-Eastern Syria

mreži. Brojni, uglavnom sezonski i povremeni pritoci spuštaju se s gorskog okvira prema Haburu i njegovu pritoku Radu. Bujičastog su karaktera i redovito su nakon proljetnih poplava ostavljali plodan mulj koji je obiljem minerala hranio tlo.

Iako pogodna za poljodjelstvo, Gornja Đezira intenzivnije se naseljava sjedilačkim stanovništvom tek za francuske uprave (1920. - 1945.) kada nastaje većina današjih gradova. Rastakanje tradicionalne agrarne strukture karakterizirane ponajprije autarkičnim i transhumantnim stočarstvom povezanim s plemenskom tradicijom te skromnim samodovoljnim poljodjelstvom počelo je nakon II. svjetskog rata. To je dijelom potaknuto imigracijama arapskog stanovništva iz Turske nakon graničnih promjena. Komercijalna poljodjelska proizvodnja razvija se od 1950-ih, uz kreditnu potporu države, a namjesništvo Hasaka prerasta u sirijsku žitnicu već 1960-ih. U novije doba, ponajviše u posljednjih tridesetak godina počinje značajnija deagrarizacija, razvoj industrije (nafta i plin), te promjene u prostornoj slici naseljenosti.

Razmjerno brz društveno-gospodarski razvoj, napose razvoj poljodjelstva, dovelo je do pretjeranog iskorištavanja prirodno razmjerno obilnih vodnih resursa, što se odrazilo na promjenama u otjecanju površinskih i podzemnih voda. Članak ima za cilj prikazati kako su se do sada koristili vodni resursi Gornje Đezire za sve veće potrebe natapanja poljoprivrednih površina te istaknuti glavne probleme uzrokovane dosadašnjim neadekvatnim upravljanjem. 


\section{PRETHODNA ISTRAŽIVANJA}

Većina istraživanja u Gornjoj Đeziri bila je geološke i hidrogeološke naravi, a u novije doba ponajprije usmjerena na tehnička rješenja oko dobave vode za potrebe natapanja u kotaru (brane, bušeni bunari). Najranije geološke i hidrogeološke radove koji su uključivali gornju Mezopotamiju objavili su L. Dubertret (1933.) i W. Willcocks (1937.). Prva istraživanja podzemnih voda u Gornjoj Đeziri provodili su D. J. Burdon (1954., 1959.), Š. Safadi (1960.) i J. Khouri (1965.). Kao početak istraživanja za potrebe FAO Šafik al Safadi i Francis Morte (1963.) opisali su u svom izvještaju važnost vode u gospodarskom razvoju sirijske Đazire. Neovisno od FAO sirijska je vlada (tadašnja Uprava za natapanje Sirije) naručila više studija korištenja voda izvora i tekućica u gornjem toku rijeke Habur: od bugarske tvrtke Bulgarian Agrocomplex Co. (1963., 1976. i 1984.) i švedske tvrtke V.B.B. (1965.). Ministarstvo poljoprivrede naručilo je studiju o zalihama podzemnih voda u namjesništvu Hasaka (Khouri et al., 1965). Godine 1966. FAO je predao Ministarstvu poljoprivrede AR Sirije završni izvještaj, odnosno podrobnu studiju o resursima vode u podzemlju u području sirijske Mezopotamije (sjeveroistočno od Eufrata). Godine 1976. Khouri i Rasoul izradili su manju studiju o vodnim resursima u okolici Kamišlija potrebnim za tadašnji program natapanja novih 1000 ha poljoprivrednog zemljišta u državnom vlasništvu. Od novijih istraživanja u namjesništvu Hassaka ističe se interni izvještaj Ministarstva poljoprivrede Sirije iz 1997. godine.

Geografskih radova koji se odnose na istraživano područje ima vrlo malo. Jedinu regionalnogeografsku studiju pod nazivom Sirijska Đezira (Al Jazira as Syria) napisao je M. Bogosijan (Boghossian, 1952.) za svoj doktorat iz geografije. A. Mardini je 1986. godine objavio popularnu knjigu koja daje opći prikaz namjesništva Hassaka. Pretežno demogeografski rad koji se odnosi na sjeveroistočni dio namjesništva Hassake objavio je G. Bahnan (1991.). Opsežna geografska istraživanja obavio je akademik Abd al Salam, koji je od 1980. do 1990. godine objavio u četiri sveska svoje djelo Geografija Sirije. Područje Hassake obrađeno je u posljednjem, 4. svesku, objavljenom 1990. godine. Istraživanog područja rubno se dotiču još geografi S. Her (1985.) u svojoj Ekonomskoj geografiji Sirije i Š. Aga (1979. i 1980.) s radovima o krajoliku i prirodnom biljnom pokrovu gornje Mezopotamije.

Hidrogeografskih radova općenito je nedovoljno u Siriji s obzirom na važnost vode kako u prirodogeografskom tako i u društvenogeografskom pogledu. Stoga se na tom području ističe rad akademika Abd Rahman Hamide, po specijalnosti hidrogeografa, koji je objavio kapitalno djelo Hidrologija Sirije (Hamida, 1962.). Iako je istraživao i u sjeveroistočnoj Siriji, na žalost nije objavio rad regionalnog značaja o Gornjoj Đeziri. U novije doba A. F. Bakar (1989.) doktorirao je na temu mogućnosti razvitka natapanja u Siriji, a hidrogeografskim istraživanjem sjeveroistočne Sirije bavi se G. Bahnan (2003.).

\section{METODA RADA I PODATCI}

Geografsko istraživanje voda uključuje razmatranje ekologije (u najširem smislu tog pojma) svekolikog geoprostora (Riđanović, 1993.). U skladu s tim osnovna postavka rada jest da su hidrogeografska obilježja usko povezana s društveno-gospodarskim razvojem 
regije, ponajprije s razvojem poljoprivrede te da je dosadašnji način gospodarenja vodom neadekvatan. Problemu se dakle pristupa s teorijskih osnova održivog razvoja.

$\mathrm{U}$ poljoprivredi u istraživanom području je važan resurs voda u podzemlju. S obzirom da je regija razmjerno dobro hidrogeološki istražena, pozornost nije usmjerena na prirodne uvjete otjecanja u podzemlju, već ponajprije na intenzitet i način korištenja vode iz podzemlja te odnos prema procijenjenim zalihama i obnovi.

Podatci su prikupljani iz dostupne službene statističke građe, među kojima je vrijedan izvor podataka statistički godišnjak Ministarstva poljoprivrede koji se redovito izdaje od 1984. godine. Osim toga korišteni su podatci iz arhiva i baza podataka u uredima Ministarstva poljoprivrede i Ministarstva natapanja. Određeni podatci preuzeti su iz literature, objavljene ili u rukopisu (elaborati). S obzirom na dostupne podatke, promjene u korištenju vodnih resursa za potrebe natapanja razmatraju se uglavnom u razdoblju od 1984. do 2000. godine.

\section{REZULTATI I RASPRAVA}

\section{Glavna obilježja poljodjelske proizvodnje}

Namjesništvo Hasaka je prema poljoprivrednoj proizvodnji najvažnija sirijska provincija. U poljoprivredi namjesništva zaposleno je oko $2 / 3$ radno aktivnog stanovništva, a u Siriji u cjelini oko 30 \%. Važnost poljoprivrede Hasake u Siriji ogleda se u usporedbi načina iskorištavanja zemljišta u namjesništvu i Siriji u cjelini (sl. 2).

Namjesništvo Hasaka ima znatno veći udio obrađenih površina u usporedbi sa Sirijom u cjelini. Za istaknuti je da obrađeno zemljište u namjesništvu Hasaka zauzima gotovo 1/4 (u razdoblju 1984. - 2000. godine između 23,5 \% i 24,8\%) svih obrađenih površina u Siriji. To potvrđuje ulogu Hasake kao žitnice Sirije, jer namjesništvo Hasaka zauzima tek 12,6 \% od ukupne površine Sirije. Pritom, poljodjelske površine zauzimaju sjeverni dio namjesništva, plodnu i humidniju zavalu Gornje Đezire. Obradivo neobrađeno zemljište čini razmjerno stalnih 4,6 \% ukupnog zemljišta kotara. Iako je taj udio razmjerno malen, ipak čini oko $1 / 5$ obradivog neobrađenog zemljišta Sirije u cjelini. Ovdje je najveći dio te kategorije zemljište ostavljeno na ugaru radi odmaranja zemlje. Stepe i pašnjaci zauzimaju oko 30 \% površine kotara. Najveći dio toga zemljišta leži u južnom dijelu namjesništva, u sušnoj Donjoj Đeziri. U tu kategoriju uračunat je i određeni udio polupustinja s oskudnom travnom vegetacijom.

Zemljišni maksimum za posjede bez natapanja je 85 ha u tzv. prvoj zoni (s više od $350 \mathrm{~mm}$ padalina godišnje, $24,8 \%$ površine namjesništva, proteže se meridionalno uz sjevernu granicu), te 120 ha u drugoj i trećoj zoni (s više od $250 \mathrm{~mm}$ padalina, zauzima ostatak zavale Gornje Đezire). U četvrtoj (200-250 mm padalina godišnje) i petoj zoni (manje od $250 \mathrm{~mm}$ padalina godišnje) koje se nalaze na jugu (Donja Đezira, zajedno zauzimaju 22,4 \% površine namjesništva) većina zemljišta je u vlasništvu države i iznamljuje 

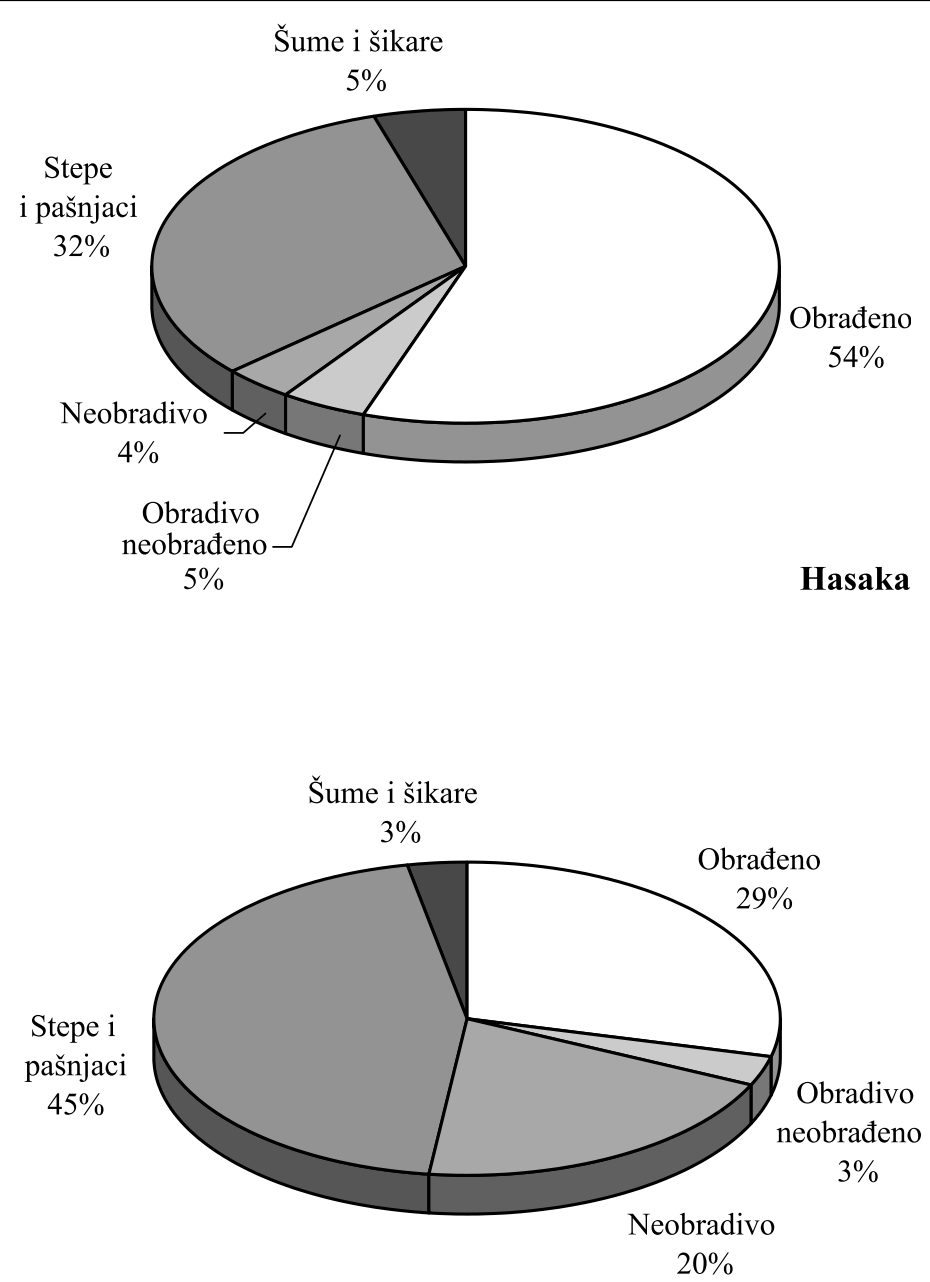

Sirija

S1. 2. Način korištenja zemljišta u namjesništvu Hasaka i u Siriji 2000. godine

Fig. 2 Land use in governorate Al Hasakah and Syria in the year 2000

Izvor: The Agricultural Statistical Abstract, Ministarstvo poljoprivrede A. R. Sirije

se uglavnom stočarima. Međutim, prosječne veličine posjeda u namjesništvu kreću se od 10 do 18 hektara. Na posjedu se zakonski smije natapati najviše 15 ha. Većina seljaka udružena je u zadruge koje određuju plan svake godine i brinu o plasmanu proizvoda. Državna proizvodnja pala je ispod $10 \%$, zadružna proizvodnja iznosi nešto iznad $50 \%$, 
a privatna proizvodnja nešto je manja od $40 \%$. Odnos privatne i zadružne proizvodnje ovisi o uzgajanim kulturama, pri čemu je proizvodnja za vlastite potrebe uglavnom privatna, a proizvodnja za tržište u zadrugama. Sve do nedavno država je planski poticala višekulturni sustav, s određenim kulturama prema poljoprivredno-padalinskim zonama. U novije vrijeme jača državna intervencija, uglavnom putem kredita kojima se više potiče uzgoj komercijalnih kultura, prvenstveno pšenice i pamuka.

U namjesništvu se najviše uzgajaju žitarice, i to pšenica i leća u krajevima s više padalina, a ječam u sušnijim krajevima. Glavna tržišna i industrijska kultura je pamuk. Na natapanim površinama najviše se uzgaja upravo pamuk i pšenica. Što se tiče pšenice od 1984. do 2000. godine bilježi se stalan porast zasijanih površina pod pšenicom, tako da su gotovo udvostručene (sl. 3).

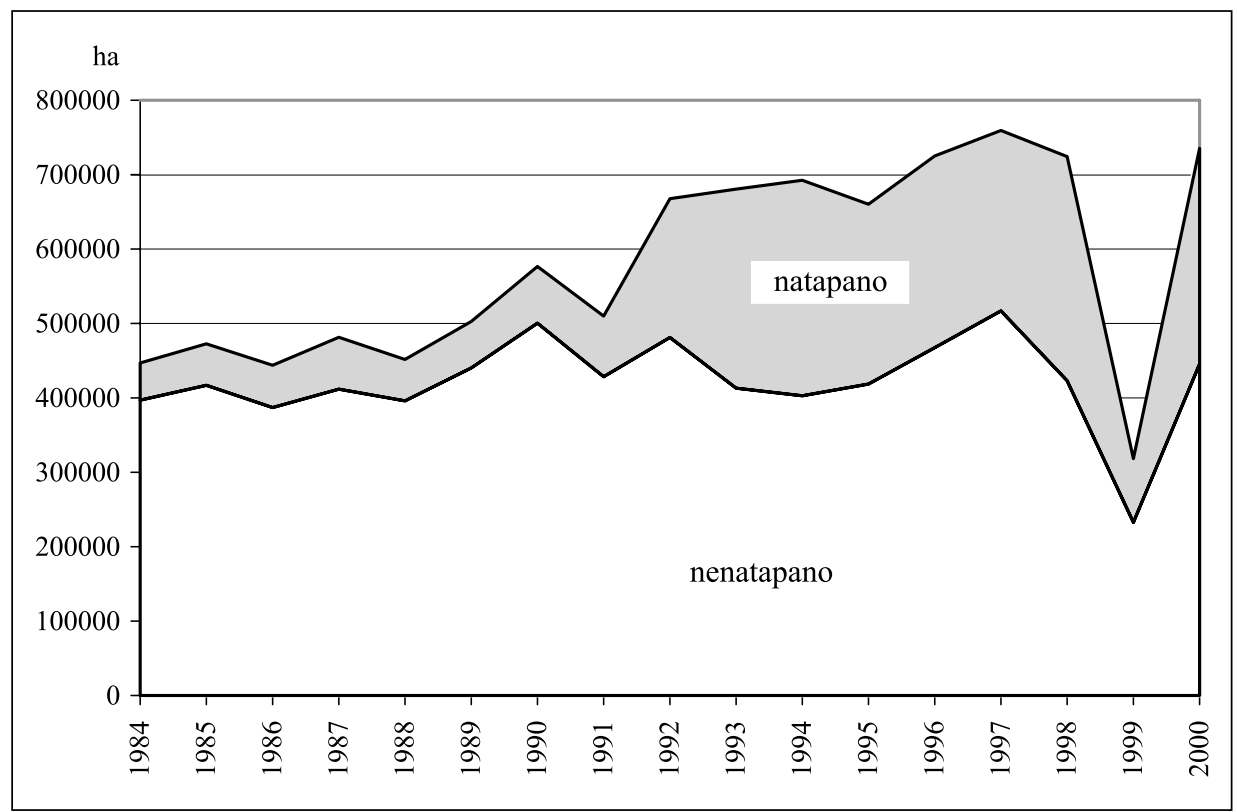

S1. 3. Ukupna te natapana i nenatapana površina pod pšenicom u namjesništvu Hasaka

Fig. 3 Total, irrigated and non-irrigated land under wheat in governorate Al Hasakah

Izvor: The Agricultural Statistical Abstract, Ministarstvo poljoprivrede A. R. Sirije

U cijelom tom razdoblju Hasaka ima oko 40 \% od svih površina pod pšenicom u Siriji. Proizvodnja pšenice (sl. 4) bila je vrlo varijabilna 1980-ih, da bi od početka 1990. narasla s oko 1 mil. t na oko 1,7 mil. t do polovice 1990-ih na kojoj razini se u načelu zadržala, a to predstavlja i oko $40 \%$ sirijske proizvodnje pšenice. Nagli porast proizvodnje 1990-ih posljedica je porasta udjela natapanih površina, koje daju veće prinose. Udio natapanih površina u ukupnoj površini pod pšenicom kretao se do 1990 . između 11 i $12 \%$ da bi zatim narastao na $16 \% 1991$., na $27,9 \%$ 1992. te na $39,3 \% 1993$. Od svega oko 76000 ha 1990. natapane površine povećale su se na gotovo 270000 ha 1993. Od tada nema značajnijih promjena, između ostalog zbog širenja drugih natapanih kultura, primjerice 


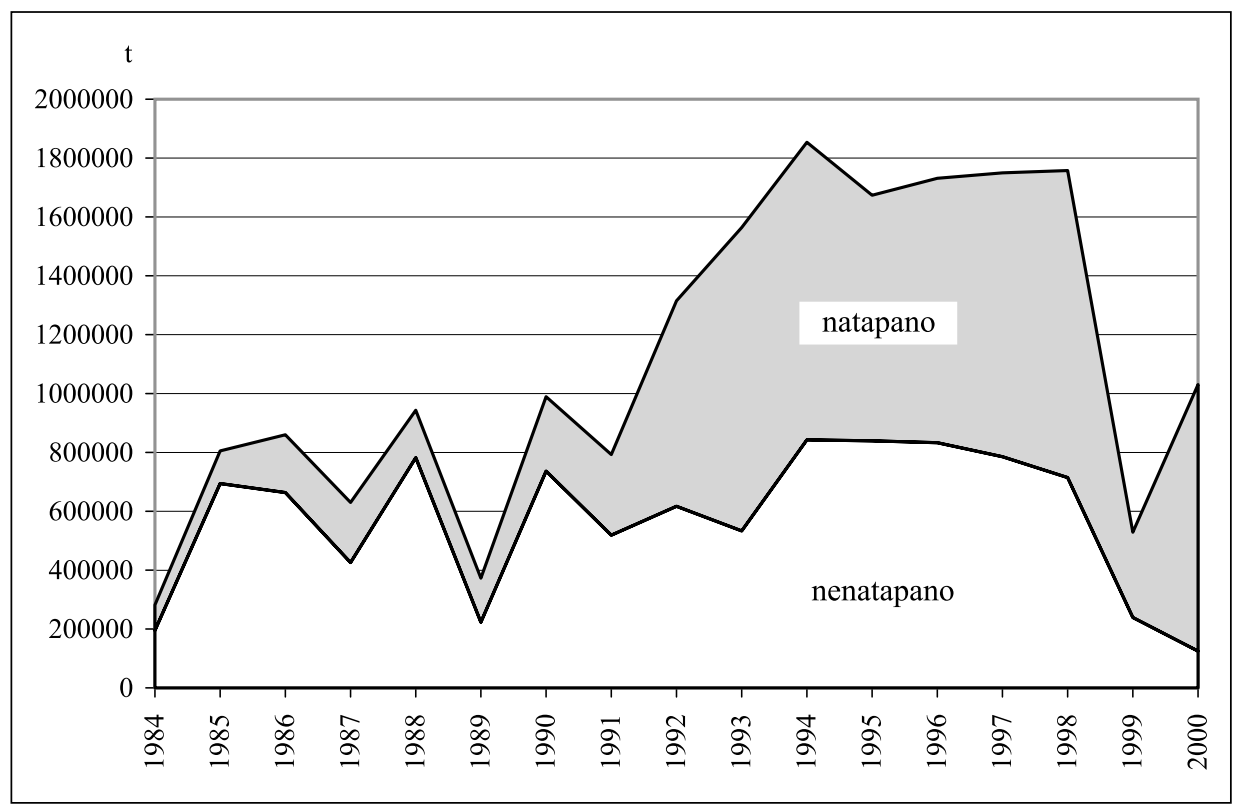

S1. 4. Ukupna proizvodnja te proizvodnja s natapane i nenatapane površine pod pšenicom u namjesništvu Hasaka

Fig. 4 Total wheat production, and wheat production from irrigated and non-irrigated land in governorate Al Hasakah

Izvor: The Agricultural Statistical Abstract, Ministarstvo poljoprivrede A. R. Sirije

pamuka. Veliki pad površina pod pšenicom 1999. godine rezultat je neadekvatnog plana te godine, ali je pad produktivnosti i rezultat loših vremenskih prilika što je vodilo lošim rezultatima na nenatapanim površinama (što se nastavilo i 2000.).

Sve površine pod pamukom (sl.5) se natapaju. Sirija je pamuk odabrala kao jedan od svojih strateških proizvoda, pa u državi postoji trend povećanja površina pod pamukom. Određene varijacije iz godine u godinu u zasijanoj površini pod pamukom i njegovoj proizvodnji posljedica su planske politike. Naime, kad je jasno da se iz brana određene godine ne može osigurati dovoljna količina vode za natapanje planski se smanje površine na kojima se sije pamuk. Ipak stalan je trend porasta uzgoja pamuka u Siriji s oko 150000 ha polovicom 1980-ih na oko 250000 ha krajem 1990-ih. Hassaka, odnosno Gornja Đazira je najvažnije područje uzgoja pamuka u Siriji, pa je također pirsutan trend porasta površina pod pamukom u navedenom razdoblju. Početkom razdoblja bilo je oko 45000 ha površina pod pamukom, da bi krajem 1990-ih bilo oko 100000 ha pod pamukom. To znači da je trend porasta površina pod pamukom u namjesništvu Hasaka bio intenzivniji nego u Siriji u cjelini. U Siriji u cjelini je indeks porasta 1998./1984. iznosio 154 \% (ako bi iz Sirije izuzeli Hasaku, onda i manje - 130 \%) dok je u Hasaki indeks porasta $u$ istom razdoblju iznosio $223 \%$, što znači da se površina pod pamukom više nego udvostručila. 


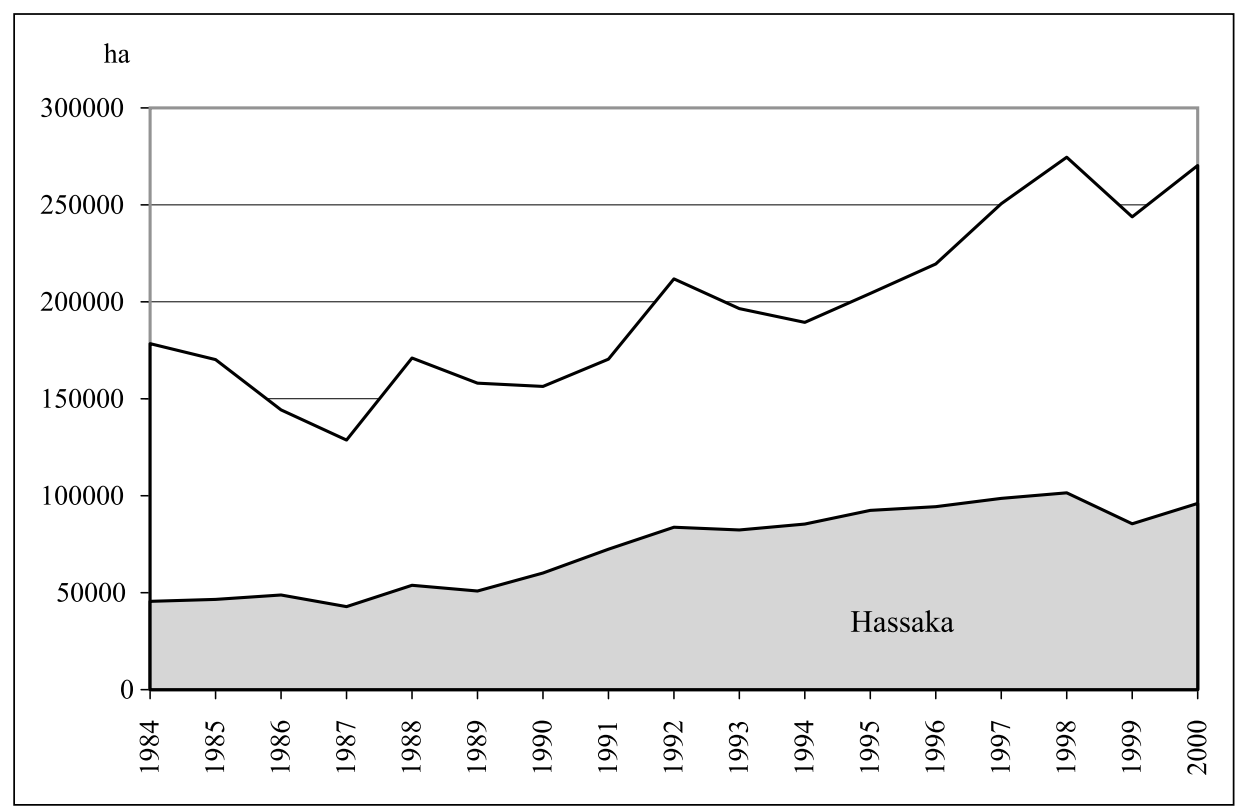

S1. 5. Površina pod pamukom u Siriji i namjesništvu Hasaka

Fig. 5 Land under cotton in Syria and governorate Al Hasakah

Izvor: The Agricultural Statistical Abstract, Ministarstvo poljoprivrede A. R. Sirije

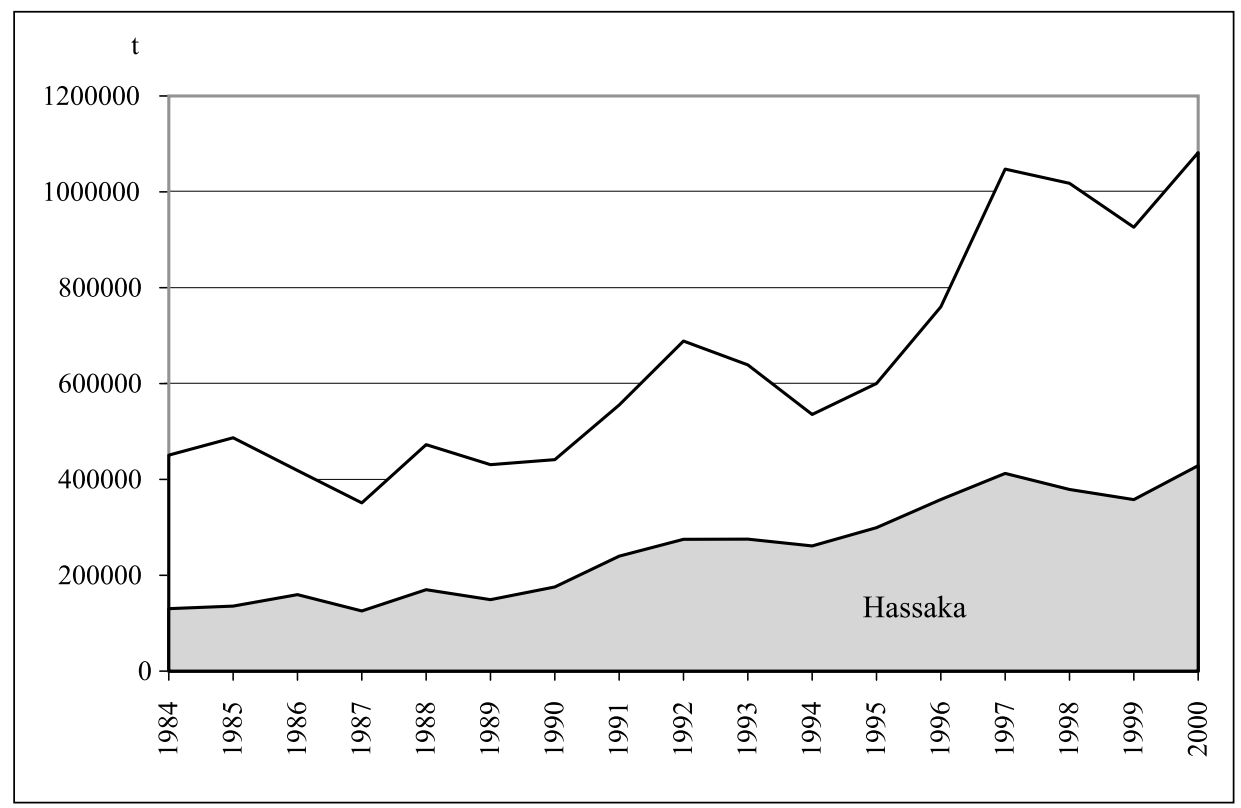

S1. 6. Proizvodnja pamuka u Siriji i u namjesništvu Hasaka

Fig. 6 Cotton production in Syria and in governorate Al Hasakah

Izvor: The Agricultural Statistical Abstract, Ministarstvo poljoprivrede A. R. Sirije 
Porast površina pod pamukom u Hasaki nešto je intenzivniji početkom 1990-ih što je između ostalog omogućeno povećanjem broja poljoprivrednih bunara, kao i izgradnjom velikih brana Hassaka-Zapad i Hassaka-Istok koje su osigurale stabilnije natapanje. Od kraja 1980-ih država je intenzivnije poticala uzgoj pamuka davanjem kredita za otvaranje poljoprivrednih bunara. U posljednje doba došlo je do problema u opskrbi iz poljoprivrednih bunara, država je morala zabraniti bušenje novih bunara, a novi projekti hidroakumulacija nisu počeli, odnosno dovršeni, pa su i površine pod pamukom za sada dosegle svoj maksimum u namjesništvu. Udio površina pod pamukom namjesništva Hasake u Siriji iznosio je 1984. 25,5 \%, da bi stalno rastao i 1995. dosegao maksimum kada je gotovo polovica (45,5 \%) svih sirijskih površina pod pamukom bila u Hasaki. Podatci za 1999. i 2000. godinu odražavaju poteškoće u opskrbi vodom, pa se može uzeti da je prema podatcima iz 1997. i 1998. udio površina Hasake pod pamukom u sirijskim površinama pod pamukom gotovo $40 \%$.

Što se tiče proizvodnje (sl. 6), ona prati porast površina pod pamukom. Do kraja 1980-ih ona se kretala između 130 i 170 tisuća tona godišnje. Nakon toga bilježi stalan rast i dosegla je 380 do 400 tisuća tona krajem 1990-ih. Proizvodnja je po svom udjelu u sirijskoj proizvodnji pamuka stalno veća od udjela površina pod pamukom, što je pokazatelj kakvoće tla i pogodne klime Hasake - nema ljetne kiše koja bi smanjila urod pamuka. Udio namjesništva u sirijskoj proizvodnji pamuka danas iznosi oko $40 \%$, a najveći je bio 1995. kada je čak polovica sirijskog pamuka proizvedena u Hasaki.

\section{Natapane površine}

U razdoblju 1984. - 2000. godine došlo je do velikog povećanja natapanog zemljišta (sl. 7) i u Siriji i u namjesništvu Hasaka. Na početku razdoblja, 1984. u Siriji je natapano 616862 ha, što je činilo oko $11 \%$ obrađenog zemljišta. Udio natapanog zemljišta udvostručen je 2000. godine tako da se u Siriji natapa oko 1,2 mil ha ili gotovo $23 \%$ obrađenog zemljišta. Pritom je u Siriji, a tako i u Hasaki došlo do zanemarljivog pada obrađenog zemljišta (za nekoliko postotaka), uglavnom radi zaslanjenja tla. Povećanje udjela natapanog zemljišta rezultat je općeg društveno-gospodarskog napretka, uporabe motrnih i električnih crpki za natapanje iz površinskih voda, izgradnje hidroakumulacija i sve većeg korištenja poljoprivrednih bunara.

U Hasaki je došlo i do većih pozitivnih promjena nego u Siriji u cjelini. Tako je 1984. bilo natapano svega 113023 ha ili samo oko 8 \% obrađenog zemljišta. Najveće promjene dogodile su se od 1992. do 1994. kada je došlo do velikog povećanja broja poljoprivrednih bunara i korištenja brana Hassaka-Zapad i Hassaka-Istok izgrađenih 1990. Vrhunac povećanja udjela natapanog zemljišta bio je 1998. kada je natapano čak $32 \%$ obrađenog zemljišta. Nakon toga, zbog ograničenja u bušenju novih bunara, dolazi do stagnacije, ali se očekuje da će nove brane kao što je Al Basel (Hassaka-Jug) ponovno podići udio natapanog zemljišta. Zaključno, upravo je dramatičan porast natapanih površina u kotaru Hassaka koji je od 1984. do 2000. godine porastao za gotovo tri i pol puta (indeks promjene $345 \%$ ). U istom razdoblju u Siriji su se natapane površine udvostručile (indeks promjene $196 \%$ ). 


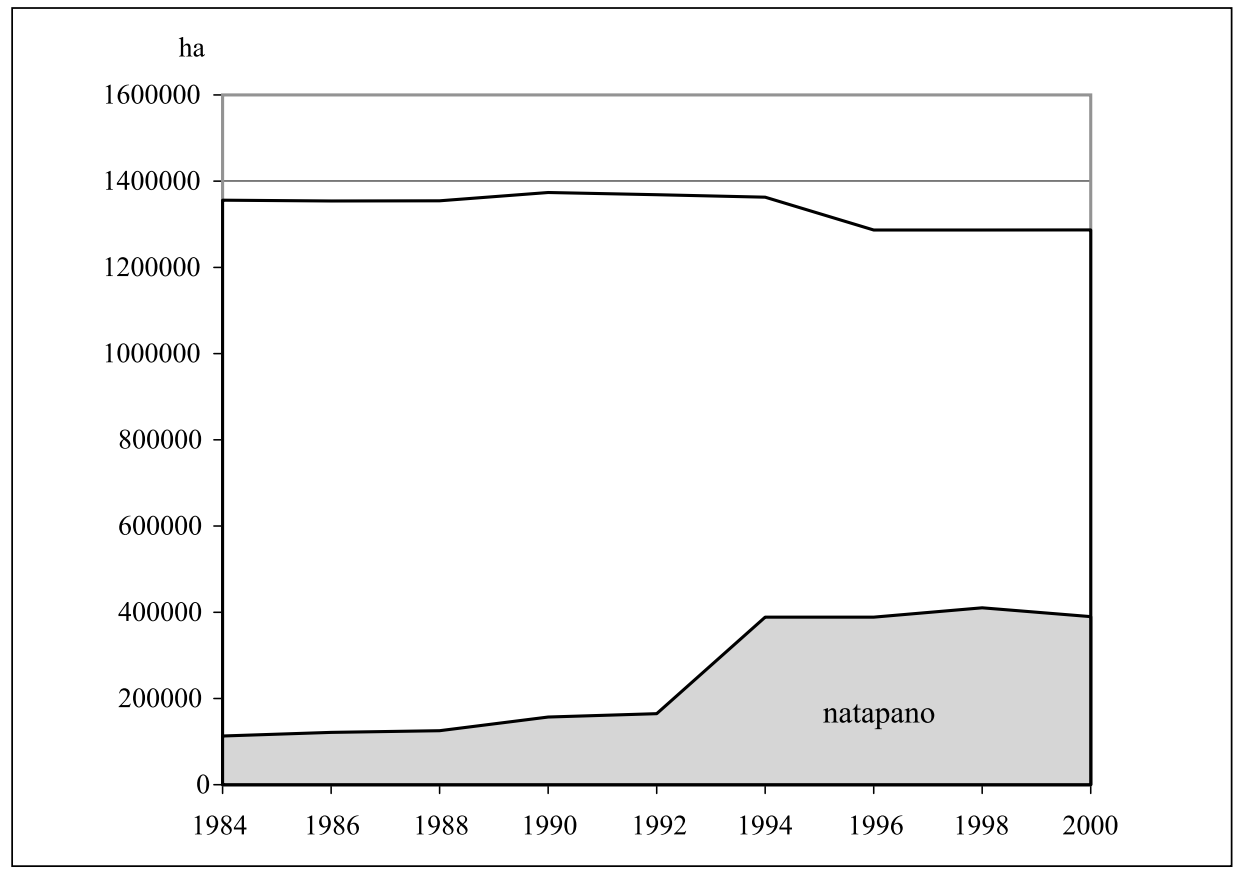

S1. 7. Natapano u obrađenom zemljištu namjesništva Hasaka

Fig. 7 Irrigated in total agricultural land in governorate Al Hasakah

Izvor: The Agricultural Statistical Abstract, Ministarstvo poljoprivrede A. R. Sirije

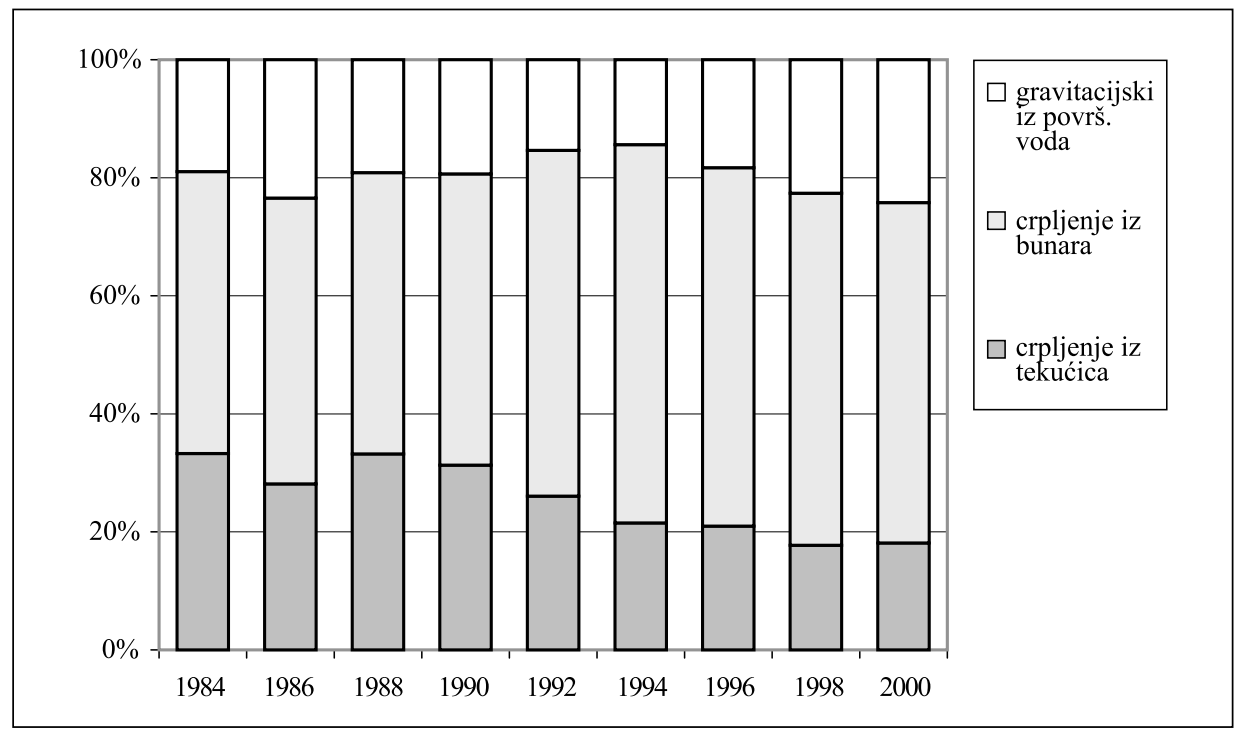

S1. 8. Izvori vode za natapanje u Siriji

Fig. 8 Water sources for irrigation in Syria

Izvor: The Agricultural Statistical Abstract, Ministarstvo poljoprivrede A. R. Sirije 


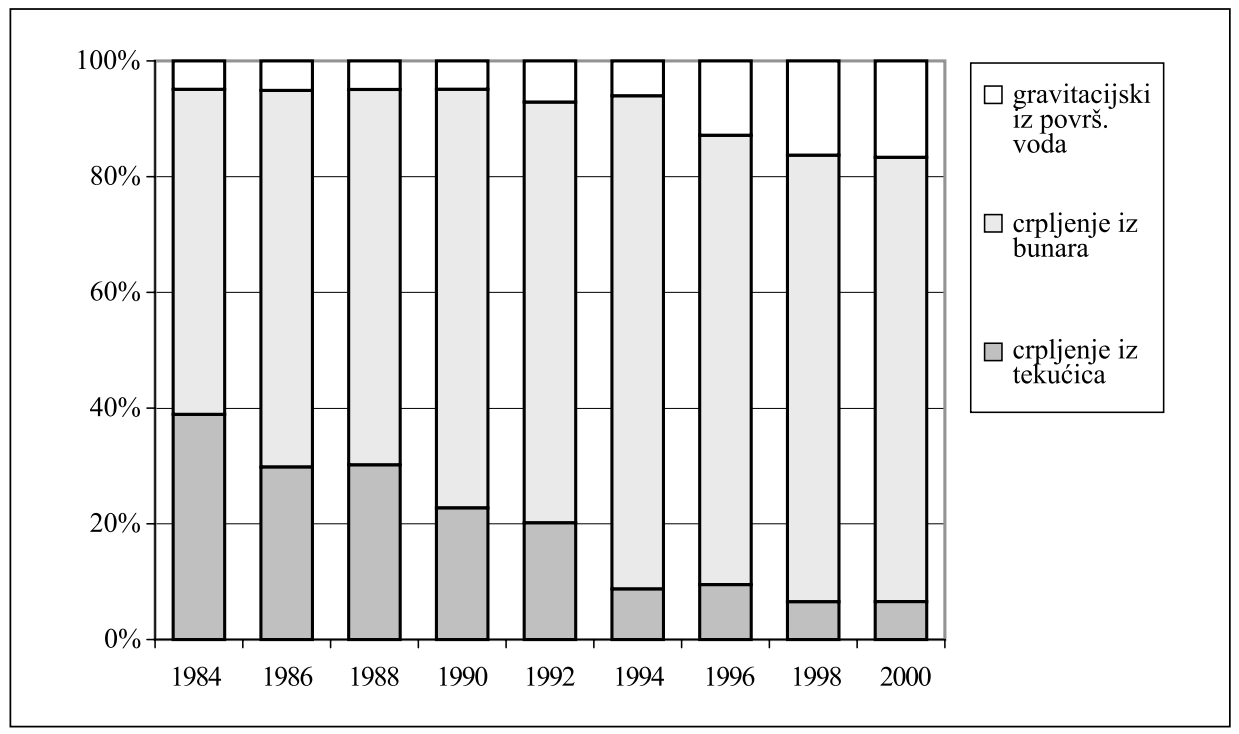

S1. 9. Izvori vode za natapanje u namjesništvu Hasaka

Fig. 9 Water sources for irrigation in governorate Al Hasakah

Izvor: The Agricultural Statistical Abstract, Ministarstvo poljoprivrede A. R. Sirije

Prema dostupnim podatcima Ministarstva poljoprivrede moguće je pratiti promjene natapanih površina prema izvoru natapanja u Hasaki i Siriji u cjelini (sl. 8 i sl. 9).

U Siriji se raspodjela udjela natapanih površina prema izvoru vode za natapanje nešto promijenila tjekom razmatranog razdoblja: Godine 1984. bila je trećina natapanih površina natapana crpljenjem iz tekućica, gotovo polovica crpljenjem iz bunara i gotovo petina gravitacijski natapana iz površinskih voda. Do godine 2000. znatnije se smanjilo natapanje crpljenjem iz tekućica (18\%) poglavito na račun natapanja iz poljoprivrednih bunara $(58 \%)$.

U namjesništvu Hasaka situacija je bitno drugačija. Na početku razdoblja nije bilo uređenih brana tako da je gravitacijsko natapanje bilo slabo zastupljeno (svega $5 \%$ ). Više nego u Siriji bilo je važno crpljenje iz tekućica. Promijenjene hidrološke prilike i državnim kreditima stimulirano bušenje poljoprivrednih bunara vodilo je velikim promjenama. Tako je 2000. godine izrazito smanjen udio površina natapan crpljenjem iz tekućica u odnosu na 1984., sa $39 \%$ na svega $6,5 \%$ svih natapanih površina, a pala je i ukupna površina koja se natapa crpljenjem iz tekućica s 44 tisuće ha na 25,5 tisuća ha. Dio površinskih voda preusmjeren je na brane tako da se sada gravitacijski natapa gotovo 17 \% natapanih površina, uz povećanje gravitacijski natapanih površina s 5550 ha (1984.) na gotovo 65000 ha (2000.). Apsolutno i relativno povećanje bilježi i natapanje crpljenjem iz bunara. Najveća zastupljenost bila je 1994. kada se na taj način natapa 85 \% natapanog zemljišta Hasake. Nakon toga slijedi pad na današnjih 3/4 natapanih površina. Ističemo da se u Hasaki nalazi gotovo 44 \% svih površina natapanih iz poljoprivrednih bunara u Siriji (1994. gotovo polovica!). Takvo stanje nije povoljno za namjesništvo, i stoga treba nastaviti s dosadašnjim naporima u izgradnji akumulacija. 


\section{Podzemne vode u natapanju}

Korištenje podzemnih voda u poljoprivredi počelo je jo 1940-ih godina, ali u doista ograničenoj mjeri. Tradicionalno je bilo važnije uzimanje vode za natapanje izravno iz tekućica. Nakon neovisnosti Sirije i određene stabilizacije naseljenosti dolazi do laganog porasta natapanja iz poljoprivrednih bunara s tim da su se tada poljoprivredni bunari iskopavali ručno. No s uvođenjem tehnologije bušenja ubrzao se porast poljoprivrednih bunara u Hasaki, tako da je već u 1980-im 50 \% natapanih površina natapano iz poljoprivrednih bunara (sl. 10). Od godine 1984. povećana je površina natapana iz bunara od zaokruženo 63,5 tis. ha na gotovo 120 tis. ha 1992. godine, dakle podvostručile su se površine natapane iz poljoprivrednih bunara u 8 godina. S obzirom na još uvijek razmjerno skromne ukupne natapane površine u odnosu na obrađene od svega oko 8 \% 1984., drugim riječima s obzirom na skromne polazne vrijednosti, porast u površinama natapanim iz bunara nije tako velik. Godine 1992. u Hassaki se natapa još uvijek prema današnjim mjerilima skromnih $12 \%$ obrađenog zemljišta (sl. 7). Ipak, u razdoblju 1984.-1992. udio natapanih površina iz poljoprivrednih bunara porasao je s 56,2 \% (1984.) na 72,7 \% (1992.), što znači da je porast natapanih površina najviše rezultat bušenja novih poljoprivrednih bunara. Upravo je najviše novih bušenih bunara nastalo na prijelazu 1980-ih i 1990-ih.

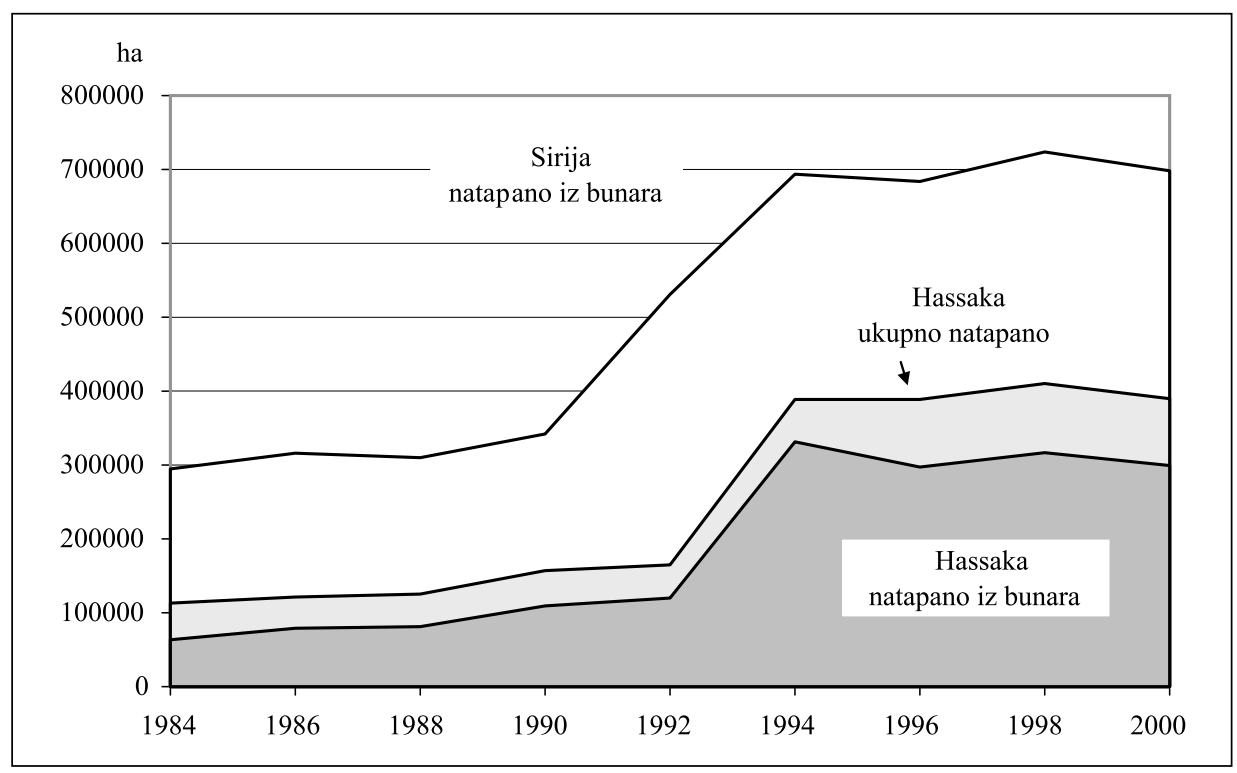

S1. 10. Površina natapana vodom iz poljoprovrednih bunara u Siriji i namjesništvu Hasaka Fig. 10 Area irrigated from agricultural wells in Syria and governorate Al Hasakah Izvor: The Agricultural Statistical Abstract, Ministarstvo poljoprivrede A. R. Sirije

Povećanje broja bunara brzo se odrazilo na dramatičan porast površina natapanih iz poljoprivrednih bunara zabilježen između 1992.i 1994. (sl. 10). Povećanje ukupno natapanog zemljišta u tom razdoblju treba pripisati ponajprije povećanju zemljišta natapanog iz bunara - ono se u dvije godine gotovo potrostručilo, s oko 120000 ha na oko 330000 ha, a 
u udjelu došlo je do porasta sa 72,7 \% (1992.) na dosad najviše zabilježenih 85,3 \%. Nakon toga dolazi do stagnacije površina natapanih iz poljoprivrednih bunara na oko 300000 ha, i to unatoč daljnjem povećanju broja poljoprivrednih bunara. Pojavili su se prvi ozbiljniji problemi povezani s prekomjernim crpljenjem vode iz poljoprivrednih bunara.

Kretanje broja poljoprivrednih bunara u kotaru započinjemo službenim podatcima Uprave za natapanje kotara Hassaka iz 1995. godine (tab. 1). Ovdje se potvrđuje iznimno brz porast broja poljoprivrednih bunara, posebno između 1980-ih i 1990-ih. Prema tim podatcima 1995. se iz 21575 bušenih bunara izvlačilo 2 298,2 mil. $\mathrm{m}^{3}$ vode godišnje i njom se natapalo 324851,1 ha. Broj ručno kopanih bunara za potrebe natapanja zanemarljiv je; njih ima svega 195 u kotaru i iz njih se dodatno izvlači 14,96 mil. $\mathrm{m}^{3}$ vode godišnje, a njom se natapalo 7687,5 ha. To bi značilo da je po hektaru iz bušenih bunara utrošeno prosječno godišnje $2298,2 \mathrm{mil}^{3} \mathrm{~m}^{3} / 324851,1 \mathrm{ha}=7074,6 \mathrm{~m}^{3} / \mathrm{ha}$. Ako bi ovi podatci bili točni radi se o višestruko prekomjernom crpljenju vode iz podzemlja. Prema procjenama (Khouri et al, 1965. i na tomu temeljen završni izvještaj za FAO 1966., interni podaci Ministarstva poljoprivrede Sirije 1995.) u podzemlje prosječno godišnje dospijeva oko 1600 do $1700 \mathrm{mil.} \mathrm{m}$ /godišnje. Ako su podatci za 1995. bili točni, to znači da se te godine izvuklo najmanje $600 \mathrm{mil} . \mathrm{m}^{3} /$ godišnje više od prirodne godišnje obnove.

Tab. 1. Kretanje broja legalno registriranih bušenih poljoprivrednih bunara u namjesništvu Hasaka, prema službenim podatcima 1995. godine

Tab. 1 Officialy registered agricultural wells in governorate Al Hasakah, report from 1995

\begin{tabular}{|l|c|c|c|c|c|c|}
\hline Godina & 1963. & 1977. & 1983. & 1990. & 1992. & 1995. \\
\hline Broj poljoprivrednih bunara & 108 & 1649 & 2895 & 9986 & 19408 & 21575 \\
\hline
\end{tabular}

Izvor: Uprava za natapanje namjesništva Hasaka, interni službeni izvještaji

Tab. 2. Kretanje ukupnog broja bušenih poljoprivrednih bunara u namjesništvu Hasaka, prema neobjavljenim podatcima, arhiva 2000. godine

Tab. 2 Total number of agricultural wells in governorate Al Hasakah according to the unpublished arhive data of the governorate's irrigation office

\begin{tabular}{|l|c|c|c|c|c|c|c|c|}
\hline Godina & 1963. & 1970. & 1975. & 1980. & 1985. & 1990. & 1995. & 2000. \\
\hline Broj poljoprivrednih bunara & 108 & 1332 & 1649 & 2793 & 3994 & 11986 & 27574 & 39742 \\
\hline
\end{tabular}

Izvor: Uprava za natapanje namjesništva Hasaka, arhiva

Upravo je zabrinjavajuće da je 2000. godine pretraživanjem arhive Uprave za natapanje namjesništva Hasaka utvrđen niz podataka o ukupnom broju bušenih bunara (tab. 2) iz kojih je razvidno da je stanje još teže. Podatci 2 000. godine uključili su i određeni broj nelegalnih bunara. Do 1985. podatci su sukladni, međutim već 1990. pokazuje se da je bilo 2000 neregistriranih bunara (16,7\%), a 1995. bilo je 5999 neregistriranih bunara (21,8\%). Dakle stvaran broj bunara premašuje za oko $20 \%$ legalno registrirane bunare. Kretanje broja bunara, dakle, možemo prikazati grafički (sl. 11) prema podatcima iz tab 2.

Prema tomu jasno se pokazuje eksponencijalan porast broja bunara u Hasaki, kako pokazuje i linija trenda unesena na grafikonu kretanja broja bunara 1963.-2000. godine, 


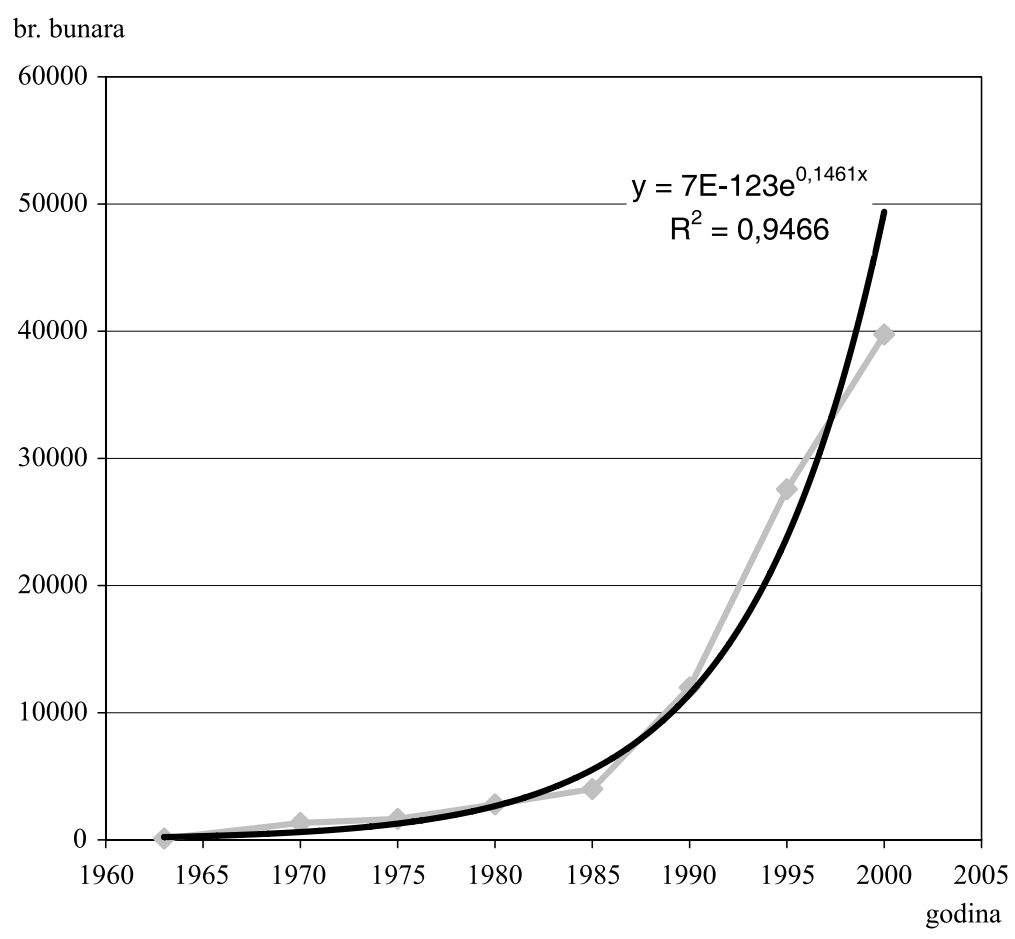

S1. 11. Kretanje broja bušenih poljoprivrednih bunara u namjesništvu Hasaka

Fig. 11 Number of agricultural wells in governorate Al Hasakah

uz statistički čvrstu vezu (koeficijent determinacije $\mathrm{R}^{2}=0,95$ ). Nakon brzog porasta od 1963. do 1970., što je razdoblje uvođenja tehnologije bušenja, uslijedio je nešto umjereniji rast od 1970. do 1985. Razdoblje od 1985. do 1995. glavno je razdoblje ekspanzije broja poljoprivrednih bunara, u tom desetogodišnjem razdoblju njihov je broj porastao gotovo 7 puta! Porast broja bunara događao se unatoč tomu što se površine natapane iz poljoprivrednih bunara, od 1994. kako je već rečeno, nisu značajnije mijenjale (oko 300000 ha). Dijelom je to rezultat prekomjernog iscrpljivanja podzemne vode, pa se stalno buše novi bunari u pokušaju zahvaćanja većih količina, a dijelom je to i stoga što su nasljednici na dijelovima očevine trebali vlastite bunare.

Poljoprivredni bunari su uglavnom pogonjeni dizel crpkama, rijetko električnim. Prema procjeni iz terenskog istraživanja i poznavanja rada i općih karakteristika crpki, iz poljoprivrednih bunara prosječno se na sat crpi $35 \mathrm{~m}^{3}$ vode. Bunari rade praktički neprekidno od 15. travnja do 15. kolovoza, oko 120 dana u poljoprivrednoj sezoni kako za pamuk, tako i za pšenicu, dvije najvažnije kulture. Gruba procjena je da se potroši godišnje:

Zahvat vode po bunaru godišnje:

$35 \mathrm{~m}^{3} \times 24$ sata $x 120$ dana $=100800 \mathrm{~m}^{3}$

Ukupni zahvat podzemne vode iz poljoprivrednih bunara u kotaru Hassaka:

Broj bunara 2000. je $39742 \times 100800 \mathrm{~m}^{3}=4005993600 \mathrm{~m}^{3}$ 
Prema ovdje iznesenim procjenama to znači da se 2000. godine uzima znatno više od ranije procjenjene godišnje količine koja dospije u podzemlje i to čak $4000 \mathrm{mil} . \mathrm{m}^{3}$ - $1700 \mathrm{mil}$. $\mathrm{m}^{3}=2300$ mil. $\mathrm{m}^{3}$ više! I približna potvrda ovakve procjene značila bi katastrofu. Zbog stalnog bušenja bunara postoji zabrinutost da se ne ponovi slučaj iz regije Salamya u središnjoj Siriji, kada je nakon stihijskog i neplanskog bušenja bunara presahla voda u podzemlju, akviferi su trajno izgubljeni, a veliki dio stanovništva ove regije preseljen je 1960-ih.

Bez obzira na točnost procjena jasno je da se radi o zaista ozbiljnoj opasnosti za vodonosnike, što potvrđuje i činjenica da su mnogi bunari presušili. Postoji jasna tendencija da se buši sve dublje, odnosno da je voda u bunarima na sve nižim razinama. Posebno je opasno ovo prekomjerno zahvaćanje, veće od prirodne obnove, jer na taj način dolazi do stlačivanja dijela vodonosnika (posebno klastita) pod geostatskim tlakom krovnih naslaga, te su ti vodnosni slojevi zauvijek izgubljeni, tj. ne mogu se više obnoviti vodom.

U računalnoj bazi Uprave za natapanje kotara Hassaka dobiveni su podatci o razinama vode u bunarima za koje postoje mjerenja. Takvih bunara je u kotaru Hassaka oko $200 \mathrm{i} \mathrm{u}$ njima se što automatski, što ručno mjeri razina vode. Od tih bunara odabrano je 72 bunara na primjeru kojih se može pokazati trend smanjivanja razine vode u poljoprivrednim bunarima. Iako većinom odražavaju stanje razine temeljnice ipak se ne mogu poistovjetiti s njom obzirom da postoji određeni broj bunara koji penetrira kroz više vodonosnika i u kojima se njihova voda miješa. Pojedini bunari danas crpe vodu s preko 100 metara dubine, a dio ih presušuje.

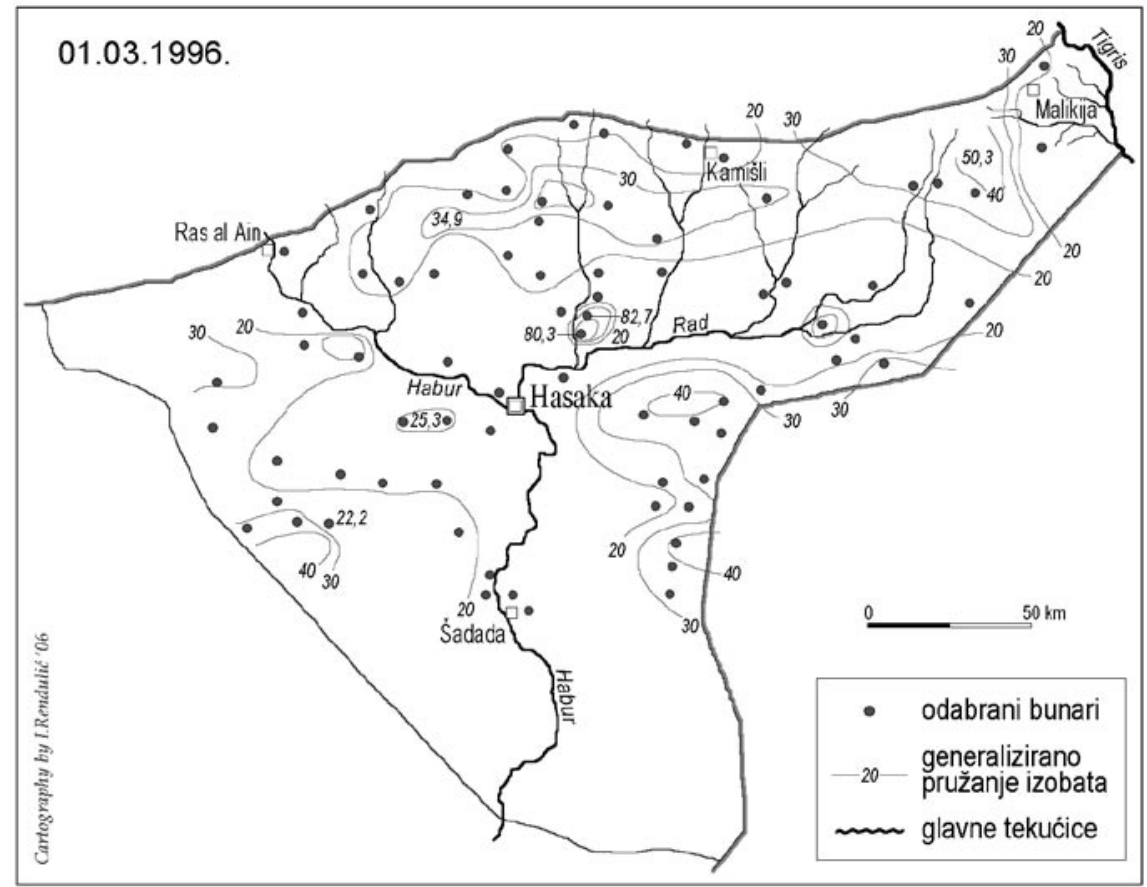

S1. 12. Izolinije razine vode u bunarima u Hasaki 1. 3. 1996.

Fig. 12 Depth of well water in governorate Al Hasakah, March $1^{\text {st }} 1996$ 


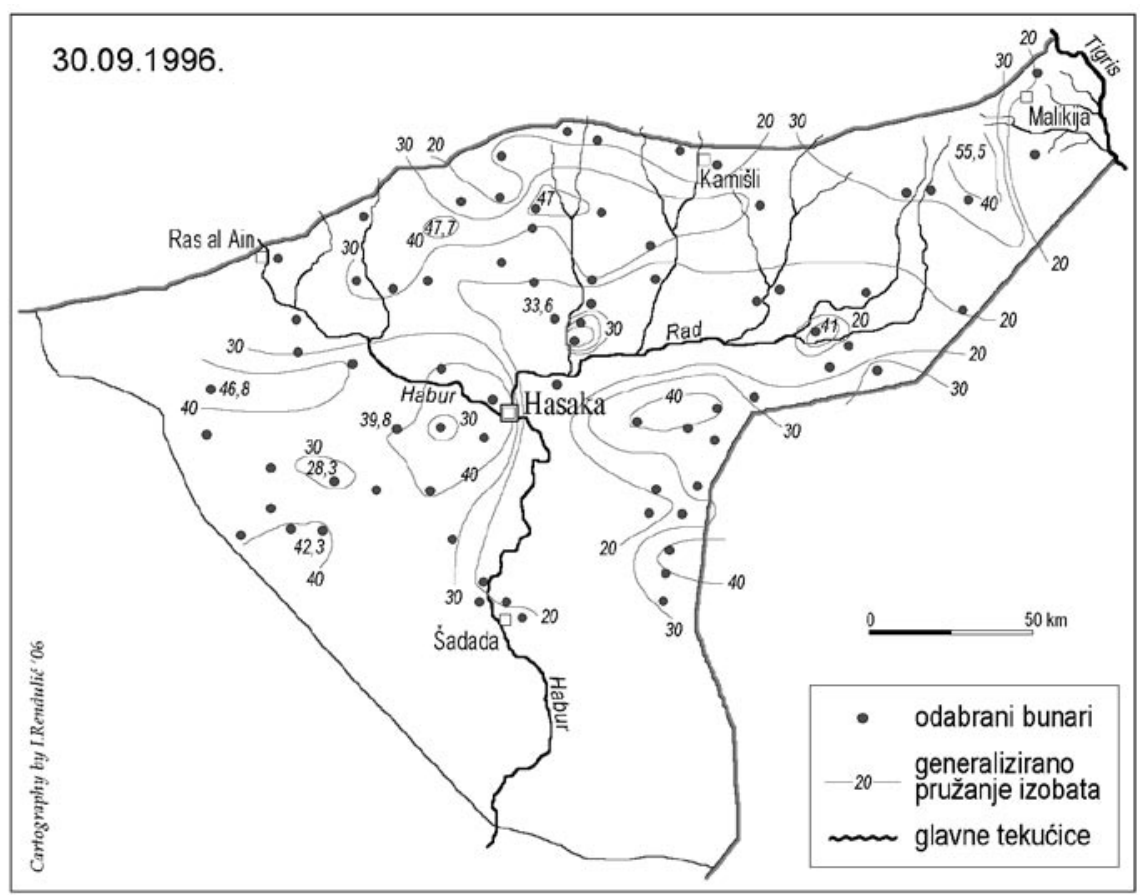

S1. 13. Izolinije razine vode u bunarima u Hasaki 30. 9. 1996.

Fig. 13 Depth of well water in governorate Al Hasakah, September $30^{\text {th }} 1996$

Na sl. 12, 13, 14 i 15 promijene možemo pratiti putem izolinija konstruiranih na temelju podataka s poljoprivrednih bunara. Prikazani su podaci o dubini do vode za 1996. i 2000. godinu, kako bi mogli provjeriti promjene u novije doba. Odabrana su dva datuma, 1. ožujak kao datum prije početka sezone natapanja i 30. rujna nakon završetka sezone natapanja. Na taj način možemo uočiti utjecaj crpljenja vode za natapanje na razinu vode u poljoprivrednim bunarima. Za očekivati je da će neposredno nakon završetka sezone natapanja razina vode $u$ bunarima biti niža nego prije nje.

Općenito možemo primijetiti da je razina do vode na sjeveru i sjeveroistoku Hasake razmjerno mala, oko 20-ak metara. Izolinijama većh dubina izdvaja se gorje Karačok koje odvaja poriječja Habura i Tigrisa. U niže položenim dijelovima padina Torosa nalazi se zona veće dubine do vode, uglavnom s vrijednostima 30-ak do 40 metara, jasnije izražena 1996. godine. Približavanjem dolini Rada, kao i dolini Habura, odnosno najnižim dijelovima zavale Gornje Đezire jasno je da je razina vode u bunarima ponovno bliže površini, uglavnom na manje od 20 metara dubine. Izolinije jasno iscrtavaju područje gore Sinđar, npr. izolinija 30 metara. Gora Abd al Aziz slabije se ocrtava, odnosno jasnije se ocrtavaju viši dijelovi gdje je dubina vode u bunarima 40-ak metara. Na jugu kotara malo je poljoprivrednih bunara.

Za razumijevanje prikaza potrebno je znati da su oko Malikije na krajnjem sjeveroistoku razmjerno manje potrebe za vodom iz bunara jer se u ovoj zoni nalazi šest hidroakumulacija koje služe za natapanje, a voda iz akumulacija puno je jeftinija od crpljene 


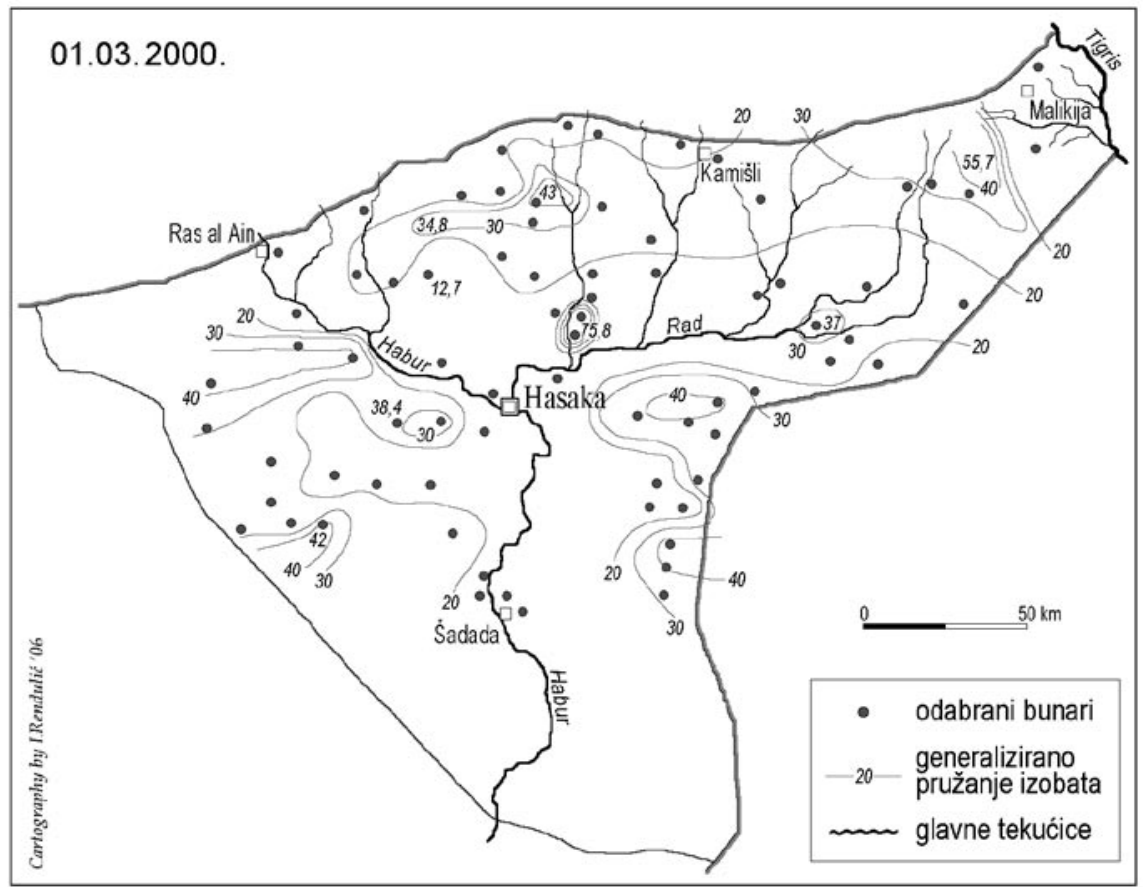

S1. 14. Izolinije razine vode u bunarima u Hasaki 1. 3. 2000.

Fig. 14 Depth of well water in governorate Al Hasakah, March $1^{\text {st }} 2000$

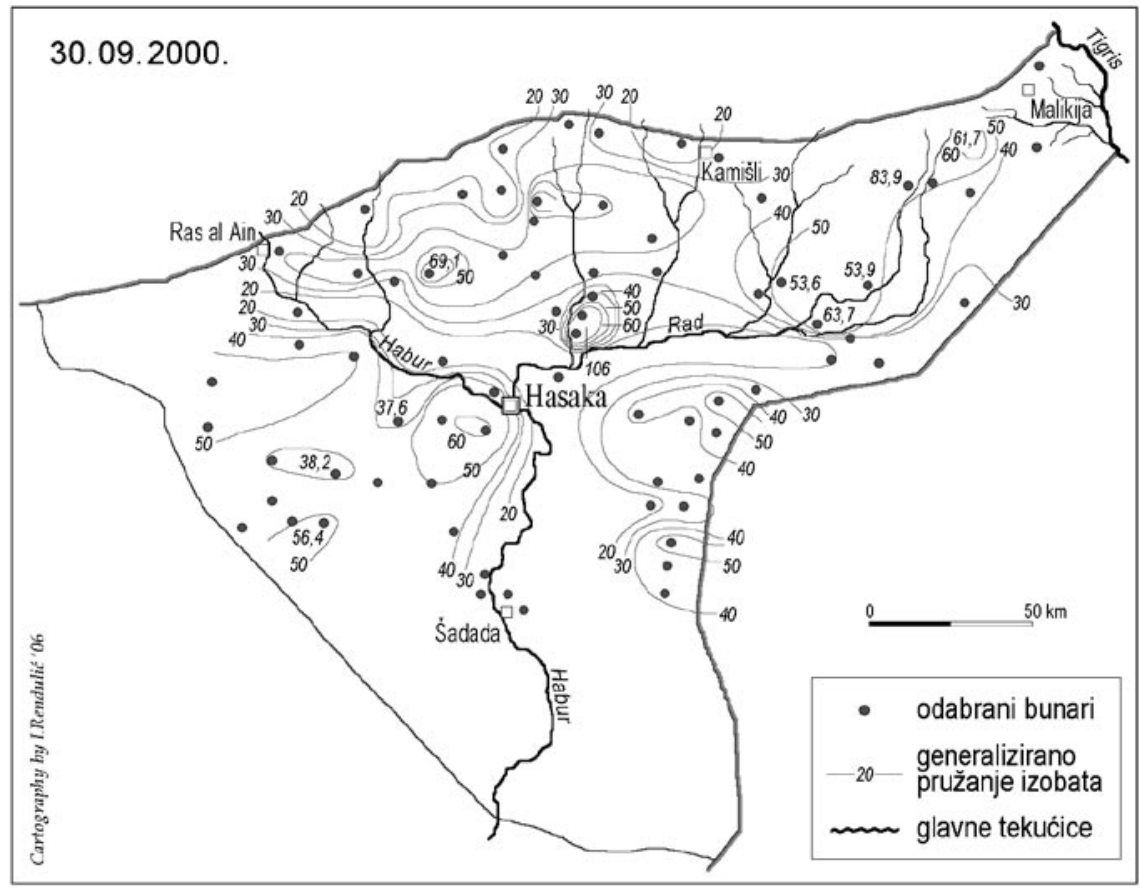

S1. 15. Izolinije razine vode u bunarima u Hasaki 30. 9. 2000.

Fig. 15 Depth of well water in governorate Al Hasakah, September $30^{\text {th }} 2000$ 
vode. Stoga su ondje, očekivano, promjene najmanje. U zoni uz Habur razlike prije i poslije natapanja, kao i između 1996. i 2000. godine također nisu izrazite, zbog korištenja vode iz Habura, odnosno iz velike hidroakumulacije Hassaka-Istok. Akumulacije Hassaka-Istok i Hassaka-Zapad pomažu održavanju razine vode temeljnice u području ispred brana. Ipak, od Habura udaljeniji bunari imaju veću dubinu do vode i veće razlike prije i poslije natapanja.

Općenito zaključuje se da su manje razlike u razini vode prije i poslije sezone crpljenja u bunarima 1996. u odnosu na 2000. godinu. Posebno su složene izolinije 30. 9. 2000. koje pokazuju da su ponegdje bunari ozbiljno iscrpljeni. Godine 1996. razlike u razini vode prije i poslije sezone natapanja opećnito nisu bile izrazite, osim u pojasu sjeverozapadnog podnožja Abd al Aziza i istočnog podnožja Abd al Aziza do Hassake. Godine 2000., osim u Malikiji i pojasu na krajnjem sjeveru, razlike su postale znatno veće u razini vode prije i poslije sezone natapanja. Sada su te razlike izrazite ne samo oko Abd al Aziza, već u cijelom središnjem dijelu sjevernog pobrđa (oko središnjih dijelova tokova s Torosa) pa i u sjeveroistočnom dijelu doline Rada, glavnim područjima uzgoja pamuka i pšenice uz intenzivnije natapanje. Zabrinjava stanje na bunaru nedaleko Ras al Aina, blizu glavnog izvorišta Habura. U tom kraju bilo je više arteških bunara, pa je i ovaj odabrani bunar 1996. prije sezone natapanja bio arteški bunar (razina vode $0 \mathrm{~m}$ ), a nakon sezone razina je pala na 6 metara dubine. Međutim 2000. godine isti bunar više nije arteški pred sezonom, jer je voda na dubini od preko $11 \mathrm{~m}$, a nakon sezone natapanja na dubini od gotovo 40 metara. Ovo je vrlo zabrinjavajuće i barem je dijelom rezultat znatno povećanog crpljenja u okolici izvorišta Ras al Ain, što je nedopustivo i uostalom dovelo je do smanjenja kapaciteta izvorišta (Bahnan, 2003.).

Izneseni rezultati u svezi poljoprivrednih bunara i intenziteta crpljenja vode iz podzemlja upućuju na zaključak da se radi o prevelikom udjelu podzemnih voda u natapanju u odnosu na površinske vode, kao i o prekomjernom crpljenju podzemne vode - svakako iznad mogućnosti prirodne obnove. Bunari se buše na sve veće dubine, sve je veći broj neregistriranih bunara, posebno u 1990-im. Trenutno se, prema terenskim opservacijama bunari koji su iskopani na 100-ak metara buše još dublje, do 200 pa i 250 metara kako bi se osigurala voda. Postoje poljoprivredni bunari u blizini izvorišta Ras al Ain koji su očito penetrirali i u drugi vodonosni kompleks što je, uz eksploataciju vodonosnika u Turskoj, jedan od uzroka dramatičnog smanjenja kapaciteta tih izvora, što je nedopustivo s obzirom na važnost Habura. To je ozbiljan problem kada se zna da je 1984. u okolici izvorišta Ras al Ain bilo 120 bunara s kojih se natapalo 2400 ha, a 1997. njihov je broj narasao na 1652 bunara s kojih se natapalo 34266 ha. Osim toga, povećalo se i natapanje izravno iz Habura i iz mreže s kanala Tal Magas ukupno cprljenjem i gravitacijski sa 37575 ha 1984. na 61150 ha 1997. godine. To znači da se u 10-ak godina povećala natapana površina vodom iz Habura, vodom njegova izvorišta Ras al Ain i iz vodom bunara u okolici njegova izvorišta ukupno sa 40-ak tis. ha (39 975 ha 1984.) na 100-ak tis. ha (98 416 ha 1997.), a važno je da je to povećanje išlo najviše zbog širenja mreže Tal Magas (koja započinje blizu izvorišta) i povećanog crpljenja iz poljoprivrednih bunara u okolici Ras al Aina. Jednako važno je istaknuti da se i u prihranskim područjima izvorišta Ras al Ain u susjednom dijelu Turske povećao broj bunara, prema dostupnim podatcima danas na oko 1000 bunara. To su glavni uzroci smanjenja izdašnosti izvorišta Ras al Ain, što se odrazilo na režim otjecanja Habura (Orešić, Bahnan, 2005.). 
Općenito kaotično iskorištavanje podzemnih resursa vode u Hasaki postalo je evidentno u upravnim strukturama, te je su krajem 1990-ih ipak poduzete neke mjere zaštite. Najvažnija je mjera bila zakonska zabrana bušenja novih poljoprivrednih bunara donesena 1998./1999. godine. Zakonski je 2000. određeno da se najviše na posjedu smije natapati 15 ha. Osim toga planiraju se poticajne mjere za ugradnju mjernih uređaja za potrošnju vode na poljoprivrednim bunarima i drugo. Da bi ovakve mjere uspješno zaštitile resurse podzemnih voda potrebno ih je strogo poštovati, odnosno zakonske odredbe strogo provoditi. U suprotnom ti bi resursi mogli biti nepovratno izgubljeni za nove generacije.

\section{Površinske vode u natapanju}

U namjesništvu Hasaka u suvremenom smislu natapanje iz površinskih izvora vode započelo je iskorištavanjem Habura kao najvećeg i najdostupnijeg vodnog resursa od 1930-ih godina. Međutim, još 1943. površina natapana na taj način iznosila je svega 8000 ha. Po ostvarenju neovisnosti Sirije država je počela s planskim proširenjem natapanih površina iz površinskih voda. To se provodi različitim poticanjem i educiranjem poljoprivrednika s jedne strane i izravnim državnim ulaganjima s druge strane.

Tijekom 1950-ih država je u kotaru Hassaka provela svoj prvi veliki projekt - izgrađen je glavni kanal za natapanje Tal Magas - Hassaka kao dio mreže kanala za natapanje uz gornji tok Habura. Protok glavnog kanala tada je iznosio $3 \mathrm{~m}^{3} / \mathrm{s}$, uporaba je počela dijelom 1952., a u punoj je uporabi od 1959. s prvotno natapanih oko 4700 ha. Također, 1956. godine država je otvorila projekt natapanja Manađir, kojim se voda izravno crpi

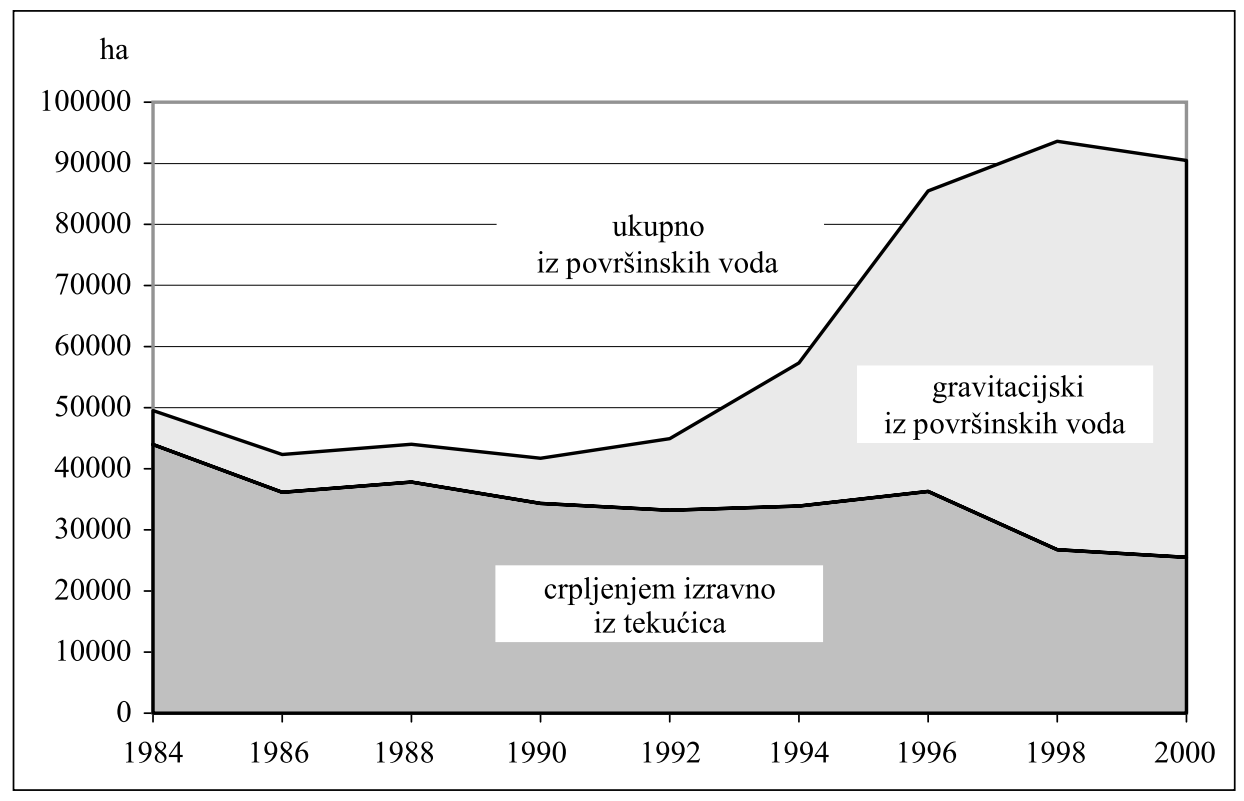

S1. 16. Zemljište natapano vodom iz površinskih voda u namjesništvu Hasaka

Fig. 16 Land irrigated from surface water resources in governorate Al Hasakah 
iz rijeke Habur i koristi za natapanje (prvotno 2400 ha). Na sjeveroistoku namjesništva, u bazenu Tigrisa također su ostvareni veći državni projekti. Uz Tigris je 1981. proveden projekt Ahmedija crpljenja vode iz Tigrisa za natapanje 1500 ha i otvorena mreža natapanja Der Dižla za 2500 ha. U Malikiji je 1970-ih ostvaren veliki projekt mreže natapanja Bab al Hadid - Gauadija koji je uključio izgradnju istoimenih brana Bab al Hadid 1972. i Gauadija 1974.

Velik poticaj poljoprivrednicima bilo je izdavanje posebnih dozvola građanima za zakonito crpljenje vode iz tekućica kako bi mogli natapati svoje zemljište. Na taj način se usporedno uz tekućice, posebice Habur, od 1951. godine ubrzano povećala površina natapana izravnim crpljenjem iz rijeka. Do početka 1970-ih to je bio najznačajniji način natapanja. Još je 1984. godine 38,9 \% natapanih površina natapano crpljenjem iz tekućica odnosno oko 44000 ha. Od tada je zabilježen lagani trend pada tih površina tako da se 1996. tako natapa 36300 ha (sl. 16). Dijelom zbog nedostatka vode u tekućicama u kojima je protok u vegetacijskom razdoblju sve manji, a dijelom zbog prelaska na druge načine natapanja, taj se udio još smanjuje. Odnos između natapanja crpljenjem izravno iz tekućica i natapanja gravitacijski iz površinskih voda bitno se promijenio tijekom 1990-ih.

Natapanje iz površinskih voda ukupno se znatno povečava od 1990. godine (sl. 16) ali sada na račun povećanja površina koja se natapaju gravitacijski iz površinskih voda. Godine 1990. bilo je 7400 ha natapanih gravitacijski iz površinskih voda u Hasaki, a 2000. oko 65000 ha, što je povečanje za preko 8,5 puta. To je ponaprije rezultat napora države

Tab. 3. Hidroakumulacije u namjesništvu Hasaka 2000. god.

Tab 3 Dams in governorate Al Hasakah, year 2000

\begin{tabular}{|c|l|l|l|l|l|l|l|l|}
\hline $\begin{array}{l}\text { Broj } \\
\text { karti u } \\
\text { prilogu }\end{array}$ & Naziv brane & $\begin{array}{l}\text { Visina } \\
\text { brane } \\
(\mathrm{m})\end{array}$ & $\begin{array}{l}\text { Duljina } \\
\text { brane i } \\
\text { nasipa } \\
(\mathrm{m})\end{array}$ & $\begin{array}{l}\text { Max. } \\
\text { površina } \\
\text { hidroak. } \\
\text { jezera } \\
\left.\text { (tis. } \mathrm{m}^{2}\right)\end{array}$ & $\begin{array}{l}\text { Max. } \\
\text { zapremina } \\
\text { hidroak. } \\
\left(\mathrm{mil} \mathrm{m}^{3}\right)\end{array}$ & $\begin{array}{l}\text { Godina } \\
\text { dovršenja }\end{array}$ & $\begin{array}{l}\text { Natapana } \\
\text { površina } \\
\text { (ha) }\end{array}$ & $\begin{array}{l}\text { Druge } \\
\text { namjene }\end{array}$ \\
\hline 1 & Hakamija & 22 & 1500 & 1210 & 6 & 1984 & 600 & nema \\
\hline 2 & Mansoura & 17 & 1532 & 726 & 3,5 & 1983 & 350 & nema \\
\hline 3 & Savan & 35 & 512 & 4075 & 50 & 1983 & 1260 & vodoopskrba \\
\hline 4 & Bab al Hadid & 22 & 610 & 3200 & 23,5 & 1972 & 2250 & nema \\
\hline 5 & Gauadija & 17 & 733 & 1485 & 8 & 1974 & 600 & nema \\
\hline 6 & Mašouk & 18,5 & 656 & 408 & 2,5 & 1980 & 220 & nema \\
\hline 7 & Đarahi & 30 & 675 & 2050 & 19,5 & 1980 & 1900 & nema \\
\hline 8 & Karima & 11 & 225 & 850 & 1,9 & 1967 & 105 & napajanje \\
stoke
\end{tabular}

Iz više izvora (Uprava za natapanje kotara Hassaka) sastavio autor 
u izgradnji brana, odnosno hidroakumulacija za natapanje. Država je planski pristupila izgradnji hidroakumulacija za natapanje i do sada je u namjesništvu Hassaka podigla deset brana i još jedna je u izgradnji (tab. 3).

Vodom s brana koje su danas u uporabi natapa se ukupno 55285 ha, pa potvrđuje da su hidroakumulacije glavni izvor za gravitacijski natapane površine (ukupno 2000. 64952 ha), a ostatak tih površina natapa se gravitacijski iz vadija ili izvora. Od deset izgrađenih brana tri su u poriječju Tigrisa i to Hakamija, Mansoura i Savan s ukupnim kapacitetom 59,5 mil. $\mathrm{m}^{3}$, a ostale su u poriječju Habura s ukupnim kapacitetom (maksimalnom zapreminom) od 355,4 mil. $\mathrm{m}^{3}$ ne računajući branu Al Basel koja je pred dovršetkom.

Brana Al Basel al Kabir ima predviđeni kapacitet 650 mil. $\mathrm{m}^{3}$, pa će njenim dovršenjem biti u poriječju Habura ukupni kapaciteti hidroakumulacija oko $1000 \mathrm{~m}^{3}$. Od toga $950 \mathrm{~m}^{3}$ kapaciteta pripada branama Hassaka-Zapad, Hassaka-Istok i Al Basel (zvana i Hasaka-Jug) koje su dio velikog projekta natapanja Habur. Projekt Habur inače se smatra drugim po važnosti projektom natapanja u Siriji, odmah nakon projekta natapanja Eufrat, a obuhvaća prostor od Ras al Aina u namjesništvu Hasaka sve do grada Sur u južnijem namjesništvu Der Az Zor, i kada se dovrši planirano je da se ukupno u sklopu tog projekta natapa 150000 ha (za uzgoj pamuka i kukuruza ljeti i pšenice i ječma zimi) uz instalaciju 24 MW električne energije.

Tigris je potencijalno velik izvor vode za natapanje i prema do sada postignutim međunarodnim dogovorima (Turska - Sirija - Irak) Sirija smije iskoristiti $20 \%$ protoka Tigrisa što pruža više nego dovoljnu osnovu za saniranje stanja u regiji, odnosno osiguranje dovoljnih količina vode za potrebe razvoja poljoprivrede u kotaru Hassaka, čak i na dosadašnjim nedovoljnjo štedljivim osnovama. Naime, radi se o mogućnosti iskorištavanja još od 3,7 mlrd. $\mathrm{m}^{3} /$ god. (protok Tigrisa prema navodima iračke strane $=18,5 \mathrm{mlrd} . \mathrm{m}^{3} /$ god.) do 5 $\mathrm{mlrd} . \mathrm{m}^{3} /$ god. (protok Tigrisa prema navodima turske strane $=25 \mathrm{mlrd} . \mathrm{m}^{3} /$ god. ). Zbog toga je kao glavni planirani projekt $\mathrm{u}$ istočnom dijelu kotara, odnosno najveći budući projekt $\mathrm{u}$ regiji isplaniran projekt Tigris za natapanje novih čak 150000 ha. Njegovim ostvarenjem značajno bi se smanjio pritisak na podzemne vodne resurse sjeveroistočne Sirije.

Naposlijetku, sadašnja potrošnja površinskih voda po hektaru može se grubo procijeniti prema podatcima Uprave za natapanje kotara Hassaka za 1995. Ti su podatci navedeni u prethodnom poglavlju - za natapanje se prema njima iz poljoprivrednih bunara iscrpilo 2,2 mlrd. $\mathrm{m}^{3}$ vode - a u njima se uz to navodi da je za natapanje iz površinskih voda potrošeno 631 mil. $\mathrm{m}^{3}$ vode. Ako taj iznos podijelimo s ukupnom površinom natapanom površinskim vodama (crpljenjem i gravitacijski iz 1994.) od 57325 ha dobijamo $11007 \mathrm{~m}^{3} / \mathrm{ha}$. Takva potrošnja po hektaru daleko je veća je od one procjenjene prema istom izvoru za površine natapane iz bunara $\left(7000 \mathrm{~m}^{3} / \mathrm{ha}\right)$. To nas upućuje na očito velike gubitke ispravanjem $\mathrm{s}$ polja i s površine kanala za natapanje, dakle dok se voda dovodi od hidroakumuluacije (ili tekućice ili izvora) kanalom do polja. Ovi gubitci mogli bi se znantno smanjiti ako se od hidroakumulacije umjesto glavnim kanalom voda dovodi glavnim cjevovodom. Naravno moguće su i veće uštede primjenom suvremenijih metoda natapanja. 


\section{Potrošnja vode za natapanje}

Do sada je razmotrena potrošnja vode u poljodjelstvu polazeći od podataka Ministarstva poljoprivrede, odnosno Uprave za natapanje o količini vode iscrpljene iz podzemlja, odnosno potrošene iz hidroakumulacija za potrebe natapanja. Na temelju iz bunara iscrpljenih 2,2 mlrd. $\mathrm{m}^{3}$ (podatci za 1995.), izračunato je da se za površine natapane iz poljoprivrednih bunara troši prosječno barem $7000 \mathrm{~m}^{3} /$ ha. U novijoj literaturi Abd al Salam je (1997.) naveo da se prosječna potrošnja u Siriji na ha zemljišta natapanog iz poljoprivrednih bunara treba zaokružiti na $8000 \mathrm{~m}^{3} /$ ha. Kada se u ovom radu pokušala procijeniti količina icrpljene vode tijekom sezone s poljoprivrednih bunara došlo se do oko $4 \mathrm{mlrd} . \mathrm{m}^{3}$ vode 2000 . godine, što ako podjelimo s površinom natapanom vodom $\mathrm{s}$ poljoprivrednih bunara iste godine (zaokruženo na 300000 ha) dovodi do zapanjujučih $13000 \mathrm{~m}^{3} / \mathrm{ha}$. Vjerojatno je ta potrošnja precijenjena ponajprije jer je natapano zemljište u novijim službenim podatcima podcijenjeno. Naime, na posjedu se sada zakonski može natapati najviše do 15 ha, čime se želi sačuvati ravnopravnost raspoložive vode za sve posjednike i sačuvati rezerve vode. Međutim, i iznad tih 15 ha zakonskog maksimuma moguće je natapati, ali ne stalno nego do dva puta godišnje. Takvo zemljište registrira se kao djelom natapano, odnosno ne ulazi u kategoriju natapano zemljište.

Na temelju podataka o potrošenoj vodi za natapanje iz hidroakumulacija (Uprava za natapanje, 1995. god.), došlo se do prosječne potrošnje od $11000 \mathrm{~m}^{3} / \mathrm{ha}$, ali dio toga treba pripisati gubicima pri dopremi vode kanalima do polja.

Prosječnu potrošnju vode po hektaru natapanog zemljišta možemo pokušati promotriti i tako da pođemo od uobičajene potrošnje za pojedine kulture, ovisno o načinu natapanja. Uzmu li se u obzir glavne kulture koje se natapaju, za pamuk je u regiji potrebno vode najmanje $4000 \mathrm{~m}^{3} /$ god., a najviše $10000 \mathrm{~m}^{3} /$ god., za pšenicu najmanje $3000 \mathrm{~m}^{3} /$ god., najviše $5000 \mathrm{~m}^{3} /$ god. i za ječam najmanje $2000 \mathrm{~m}^{3} /$ god. a najviše $4000 \mathrm{~m}^{3} /$ god. (LatifA., 1984.). Uzme li da se u namjesništvu Hasaka s obzirom na tradicionalan način natapanja troše maksimalne količine vode po hektaru, može se procijeniti poljodjelsku potrošnja u Hasaki po glavnim kulturama 2000. godine ovako:

Pamuk 96021 ha $x 10000 \mathrm{~m}^{3}=960210000 \mathrm{~m}^{3}$ vode godišnje

Pšenica 289911 ha $x 5000 \mathrm{~m}^{3}=1449555000 \mathrm{~m}^{3}$ vode godišnje

Ječam 4083 ha $x 4000 \mathrm{~m}^{3}=16332000 \mathrm{~m}^{3}$ vode godišnje

Što bi zbrojno iznosilo $2426097000 \mathrm{~m}^{3} /$ godišnje ili zaokruženo 2,4 mlrd. m³/god, odnosno ako se pridoda još za ostale malo zastupljene kulture koje se natapaju u kotaru

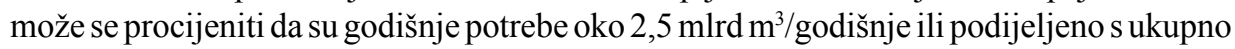
natapanim zemljištem 2000. godine (389778 ha) oko $6400 \mathrm{~m}^{3} /$ god. po hektaru.

To bi donekle odgovaralo godišnjim obnovljivim resursima vode u namjesništvu Hasaka - prema najnovije potvrđenim procjenama Ministarstva za poljoprivredu (Hadid, 1990.): oko $1,6 \mathrm{mlrd} . \mathrm{m}^{3} /$ god. podzemnih voda $+0,8 \mathrm{mlrd} . \mathrm{m}^{3} /$ god. površinskih voda $=$ ukupno oko 2,4 mlrd. $\mathrm{m}^{3}$ vode godišnje. Međutim, kako je razvidno iz podataka o utrošku vode za natapanje po pojedinim kulturama, moguće je znatno smanjiti potrošnju, najmanje na polovicu ako se uvede suvremeno natapanje prskanjem i nakapno natapanje i uvede 
doprema vode od hidroakumulacija do polja cijevima. To znači da bi se moglo potrošiti svega oko 1,25 mlrd. m³/god., a ostalo bi obnovljivih resursa u namjesništvu Hasaka još gotovo toliko, što je moguće dijelom iskoristiti.

U namjesništvu Hasaka troši se pak znatno više: najmanje $7000 \mathrm{~m}^{3} /$ ha natapanjem iz bunara (možda i znatno više - do $13000 \mathrm{~m}^{3} /$ ha) i oko $11000 \mathrm{~m}^{3} /$ ha natapanjem iz površinskih voda (zbog gubitaka isparavanjem u kanalima). To je iznad obnovljivih resursa vode u kotaru Hassaka, a s obzirom na posebno opterećenje iskorištavanja podzemnih resursa vodi u njihovo uništenje.

\section{ZAKLJUČAK}

Za istraživano područje može se reći da je voda odlučujuće utjecala na dosadašnji društveno-gospodarski razvoj te je njezino plansko iskorištavanje preduvjet daljnjeg održivog razvitka. Teorijske postavke održivog razvitka imaju daju čvrstu osnovu ovakvom razmatranju odnosa. O raspoloživim količinama ovisi i poljoprivreda kraja. To je tim važnije što je namjesništvo Hasaka na sjeveroistoku Sirije glavno sirijsko područje poljoprivredne, posebice poljodjelske proizvodnje. Poljodjelstvo je razvijeno u sjevernom, humidnijem dijelu namjesništva kojeg čini plodna zavala Gornja Đezira. Komercijalna poljodjelska proizvodnja razvija se od 1950-ih, uz kreditnu potporu države, a namjesništvo Hasaka prerasta u sirijsku žitnicu već 1960-ih.

Obrađeno zemljište u namjesništvu Hasaka čini čak oko $1 / 4$ obrađena zemljišta Sirije, iako ukupna površina namjesništva čini 12,6 \% površine Sirije. Najvažnije kulture su žitarice i pamuk. Hasaka proizvodi oko 40-ak \% žita i 40-ak \% pamuka u Siriji. To su ujedno glavne natapane kulture. Natapa se 30 -ak \% obrađenih površina, a zbog ograničenja u bušenju bunara i iscrpljenosti sadašnjih izvora za natapanje udio natapanih površina stagnira. Najviše se zemljišta natapa vodom iz poljoprivrednih bunara, oko 3/4 natapanih površina. To predstavlja golemo opterećenje na vodne resurse u podzemlju. Čak oko 40 \% sirijskog zemljišta natapanog iz poljoprivrednih bunara nalazi se u Hasaki. Broj poljoprivrednih bunara naglo je porastao potkraj XX. st., dijelom nekontrolirano i ilegalno. Poduzete su određene mjere daljnjeg ograničavanja.

Procijenjuje se da se iz podzemlja uzima više vode nego što se godišnje obnovi. To znači da je upravljanje resursima za potrebe natapanja neadekvatno i nije u skladu s održivim razvojem. Pretjerano crpljenje vode iz podzemlja odražava se na sve nižoj razini vode u poljoprivrednim bunarima kao i sve većim razlikama u razini vode u njima između početka i kraja sezone natapanja. Pojedini bunari danas crpe vodu s preko 100 metara dubine, a dio ih presušuje.

Površinske vode u natapanju razmjerno dugo su se koristile dijelom neadekvatno, izravnim crpljenjem iz tekućica, uz razmjerno malo akumulacija. Od 1980-ih i posebno nakon dovršenja brana Hasaka-Istok i Hasaka-Zapad 1990. stanje se znatno popravlja. Godine 1990. bilo je 7400 ha natapanih gravitacijski iz površinskih voda u Hasaki, a 2000. 
oko 65000 ha, što je povećanje za preko 8,5 puta. To je ponaprije rezultat napora države u izgradnji brana. Predviđeni su novi projekti vezani uz Habur i Tigris.

S obzirom da je potrošnja vode za natapanje po hektaru procjenjena na najmanje $7000 \mathrm{~m}^{3} /$ ha pri natapanju iz bunara i na oko $11000 \mathrm{~m}^{3} /$ ha pri natapanju iz površinskih voda jasno je da je potrebno provesti planske mjere kako bi se učinkovitije upravljalo vodnim resursima i spriječile buduće negativne posljedice ne samo za regiju nego i Siriju u cjelini. Određene sadašnje negativne reakcije okoliša jasno upozoravaju na opasnost. Potrebno je smanjiti pretjerano i dobrim dijelom neplansko iskorištavanje vode iz podzemlja kako bi se sačuvali akviferi, odnosno podzemni vodni resursi. Treba povećati udio natapanih površina iz akumulacija i treba osuvremeniti način natapanja kako bi se gubici sveli na prihvatljivu mjeru.

\section{LITERATURA}

Abd al Salam, A., 1990: Opća geografija Sirije. Sveučilišna naklada, svezak 4 (ukupno 4 sveska), na arapskom, Damask.

Adb al Salam, A., 1997: Sirija. Sveučilišnanaklada, Damask

Aga, ̌̆., 1979: Čovjek i geografska prirodna sredina u gornjoj Mezopotamiji. Geografski glasnik, na arapskom, Damask.

Aga, Š., 1980: Prirodni biljni pokrov gornje Mezopotamije. Geografski glasnik, na arapskom, Damask.

Bahnan, G., 2003: Hidrogeografske osnove razvoja naseljenosti kotara hassaka u sjeveroistočnoj Siriji. Doktorska disertacija. Geografski odsjek PMF-a, Zagreb.

Boghossian, M., 1952: Srijska Đezira. Doktorska disertacija. Sveučilište Sv. Josip u Bejrutu, Geografski odsjek, na arapskom, Bejrut. Djelom objavljeno: Bohhossian, M. (1956.): Une région particuliere: La Djezirah. Annales de la Faculte de Droit de l’Universite Saint Joseph, vol. 1, Bejrut.

Burdon, D. J., 1954: Report to the Government of the United Arab Republic on Ground-water Developement and Conservation in Syria. FAO ETAP-report Nr, 1270, Rim, 1954.

Burdon, D. J., 1959: Spring al Hol. Inženjerski glasnik, vol. 96, Damask.

Dubertret, L., 1933: L'hydrologie et apercu sur l'hydrographie de la Syrie at du Liban dans leurs realtions avec la géologie. RGPGD vol. 6., Paris.

Hadid, B (edit.), 1990: Workshop on Water Resources Development Strategy under Drought Conditions. ACSAD Conference, Water Resources Division, Damascus.

Hamida, A.-R., 1962: Hidrologija Sirije. Sveučilišna naklada, na arapskom, Damask.

Her, S., 1985: Sirija. Ekonomska geografija. Sveučilišna naklada, na arapskom, Damask.

Khouri, J. et al., 1965: Podzemne vode namjesništva Hassaka. Tehnički izvještaj. Ministarstvo poljoprivrede A. R. Sirije, rukopis u Arhivu Ministarstva, na arapskom, Damask.

Khouri, J., Rasoul Agha, W., 1976: Projekt natapanja 1000 ha u okolici Kamišlija. Studija. Ministarstvo poljoprivrede A. R. Sirija, na arapskom, Damask.

Khouri, J., Rasoul Agha, W., 1977: Groundwater in the Syrian Arab Republic. ACSAD, World report, lepo.

Latif, A. R., 1984: Water and plant life. Mosul 
Mardini, A.,1986: Namjesništvo Hassaka. Vlastito izdanje, Damask.

Orešić, D, Bahnan, G., 2005: Promjene režima otjecanja tekućica u gornjem dijelu poriječja Habura u sjeveroistočnoj Siriji u drugoj polovici XX. stoljeća - dio I: godišnji protoci. Hrvatski geografski glasnik, HGD, Zagreb.

Riđanović, J., 1993: Hidrogeografija. Školska knjiga, Zagreb.

Safadi, Š., 1960: Vodni resursi Gornje Đezire. Inženjerski glasnik, vol. 102, na arapskom, Damask.

Safadi, Š., Morte, F., 1963: Izvještaj za FAO. Ministarstvo poljoprivrede A. R. Sirije, rukopis u Arhivu Ministarstva, na arapskom, Damask.

V.B.B. 1965: Habour Damm Contruction Projest. A Report to the Syrian Government. Ministarstvo natapanja A. R. Sirije, rukopis u Arhivu Ministarstva, Damask.

Willcocks, W., 1937: Raj između Adena i rijeke Jordan. Uprava natapanja Iraka, Bagdad.

\title{
IZVORI
}

Arhiva Ministarstva za natapanje A. R. Sirije

Arhiva Ministarstva poljoprivrede A. R. Sirije

Arhiva Uprave za natapanje namjesništva Hasaka, Hasaka.

Bulgarian Agrocomplex Co. (1963.): Projekt natapanja i poboljšanja kvalitete tla u dolini rijeke Habur. Tehnički i ekonomski izvještaj. Studija Uprave za natapanje A. R. Sirije, Arhiv Ministarstva natapanja A. R. Sirije, na arapskom, Damask, Sofija.

The Annual Agricultural Statistical Abstract. Ministarstvo poljoprivrede A. R. Sirije, Damask.

\section{SUMMARY}

\section{Water Resources in Agriculture in North-Eastern Syria (Governorate Al Hasakah)}

\author{
Danijel Orešić, Georgos Bahnan
}

Water resources play a significant role in overall development and an adequate water resource management is necessary for sustainable development of the region in future. Water resources are very important for agriculture in this largely semi-arid part of Syria. This is emphasised by the fact that the Al Hasakah governorate (province) in North-Eastern Syria is the most important agricultural region in the country. Farming is developed in the more humid northern part of the governorate, in the Upper Jazirah fertile basin. Commercial agriculture began in the 1950's, and with the government support and planning, by the 1960's, the province became a true Syrian granary. However, this transformation was fast and largely poorly managed. 
Cultivated area makes over half of the governorate area and more importantly about $1 / 4$ of the cultivated land in Syria although the province makes only $12,6 \%$ of the total Syrian area. Wheat and cotton are the most important crops. Governorate $\mathrm{Al}$ Hasakah produces about $40 \%$ of Syrian wheat production and about $40 \%$ of Syrian cotton production. These are also the main irrigated crops. About $30 \%$ of the cultivated land is irrigated. The share of the irrigated land is stagnant for some time because of the strain on the water resources available today. Most of the irrigated land, about 3/4 of it, is irrigated from agricultural wells. This represents a huge pressure on the underground water resources. About $40 \%$ of the total Syrian area irrigated from wells is in Al Hasakah governorate. A number of agricultural wells has grown fast and partly uncontrolled and illegal. Most of the dieselpowered water pumps were introduced in the 1980's, and a number of agricultural wells grew especially fast after 1985. Legal measures have been introduced to control and restrain further growth.

It is estimated that more water is taken annually from the underground sources than it is naturally replenished. It means that the water resource management in agriculture is inadequate and not in concordance with the principles of sustainable development. The overuse of the ground-water is reflected in lower levels of water in the agricultural wells over the years, as well as in greater differences in the water levels before and after the irrigation season. Some agricultural wells are today pumping water from more than 100 meters deep and some have dried up.

Surface water sources for irrigation have been used inadequately for quite a long time, mostly by direct intake (pumping) from streams and there are few dams. This has been changing since the 1980's when more dams and canal networks were constructed, and especially after the irrigation systems Al Hasakah East and Al Hasakah West were completed in 1990. In the year 1990 there where 7400 ha of land gravitationally irrigated from the surface water sources in Al Hasakah governorate and in the year 2000 it grew up to $65000 \mathrm{ha}$ - a growth of more than 8.5 times. This was achieved primarily through government projects. New irrigation projects are considered in relation to the Khabour River and more importantly to the Tigris River on the eastern border, in accordance with international agreements.

In governorate $\mathrm{Al}$ Hasakah the usage of water in irrigation is presently estimated at minimum of $7000 \mathrm{~m}^{3} /$ ha when irrigated from agricultural wells and at about $11000 \mathrm{~m}^{3} / \mathrm{ha}$ when irrigated from the surface waters. From this data alone it is evident that planning measures are needed so that water resources could be efficiently managed. Only doing so future negative consequences for the region, as well as for the AR Syria, can be avoided. Certain present negative environmental reactions are a clear warning to us. It is necessary to lower the usage of the underground water resources in irrigation. They are clearly overused and aquifers are in danger. It is necessary and possible to enlarge the share of farming land irrigated from the surface sources. Also modern irrigations techniques are needed so that the evaporation loses could be cut down to acceptable values.

Primljeno (Received): 20 - 02 - 2006

Prihvaćeno (Accepted): 18 - 05 - 2006

Danijel Orešić, dr. sc., docent Geografski odsjek, Prirodoslovno-matematički fakultet, Marulićev trg 19/II, Zagreb, Hrvatska/Croatia e-mail: doresic@geog.pmf.hr

Georgos Bahnan, Ph. D.

Department of Geography, Facultyof Arts, Al-Mezzeh, Damascus, Syria e-mail: GeorgBahnan@hotmail.com 